\title{
Review
}

\section{DNA methylation and the regulation of gene transcription}

\author{
J. T. Attwood ${ }^{a, *}$, R. L. Yung ${ }^{a}$ and B. C. Richardson ${ }^{b}$ \\ a Department of Internal Medicine, Division of Rheumatology, University of Michigan, Taubman Center, Box 0358, \\ 1500 East Medical Center Drive, Ann Arbor, Michigan 48109 (USA) \\ b Veterans Affairs Hospital, Ann Arbor, Michigan 48105 (USA), Fax +1 734763 1253, e-mail: jattwood@umich.edu
}

Received 2 July 2001; received after revision 22 August 2001; accepted 23 August 2001

\begin{abstract}
The regulation of gene transcription is not simply dependent on the presence or absence of DNA-binding transcription factors that turn genes on or off, but also involves processes determining the ability of transcription factors to gain access to and bind their target DNA. Methylation of DNA cytosine bases leads to the inaccessibility of DNA regulatory elements to their transcription factors by a number of mechanisms. Our understanding of DNA methylation has advanced rapidly in recent years with the identification of an increasingly large number of novel proteins involved in this process. These include methylcytosine-binding proteins as well as additional members of the DNA methyltransferase family. The cre-
\end{abstract}

ation of mice with targeted deletions in a number of genes involved in DNA methylation has further elucidated the functions of many of these proteins. The characterization of complexes that contain proteins known to be involved in DNA methylation has led to the identification of additional proteins, especially those involved in histone deacetylation, indicating that DNA methylation and histone deacetylation very likely act in a synergistic fashion to regulate gene transcription. Finally, the implication of DNA methylation in tumorigenesis and the realization that some congenital diseases are caused by deficiency of proteins involved in DNA methylation has confirmed the importance of this process in regulating gene expression.

Key words. DNA methylation; methylcytosine; gene regulation; methyltransferase; methylcytosine-binding protein; chromatin; histone deacetylase; genomic imprinting.

\section{Methylcytosine, CG dinucleotides and CpG islands}

First discovered over 50 years ago in calf thymus [1], methylation of DNA occurs mostly at the 5 position of cytosine in higher eukaryotic cells (fig. 1). Although approximately $4 \%$ of cytosines present in the genome are methylated, all of the methylcytosine residues are found in the context of 5'-cytosine guanine-3' (CG) dinucleotides, of which $\sim 70-80 \%$ contain methylcytosine (for early reviews see [2,3]). Of great functional significance is the fact that methylcytosines occur in a nonrandom distribution throughout the genome [4]. When DNA is analyzed for CG dinucleotide pairs, regions with higher proportions of $\mathrm{CG}$

\footnotetext{
* Corresponding author.
}

sequences than would be expected by chance are found to exist [5]. Such CG-rich regions, referred to as $\mathrm{CpG}$ islands, constitute between 1 and $2 \%$ of the total genome, but account for most of the nonmethylated CG dinucleotides. The remaining $\mathrm{CG}$ dinucleotides occur outside of $\mathrm{CpG}$ islands and are largely methylated. $\mathrm{CpG}$ islands have been identified in organisms with large genomes such as vertebrates and some higher plants [6]. A connection between $\mathrm{CpG}$ islands and gene structure first became apparent with the finding that regions of the genome accessible to nucleases, and therefore likely to be involved in active gene transcription, contained hypomethylated DNA [4]. Further studies on CG dinucleotide distribution found that their frequency was higher at the $5^{\prime}$ end compared to the $3^{\prime}$ end of 15 randomly selected genes [5]. 


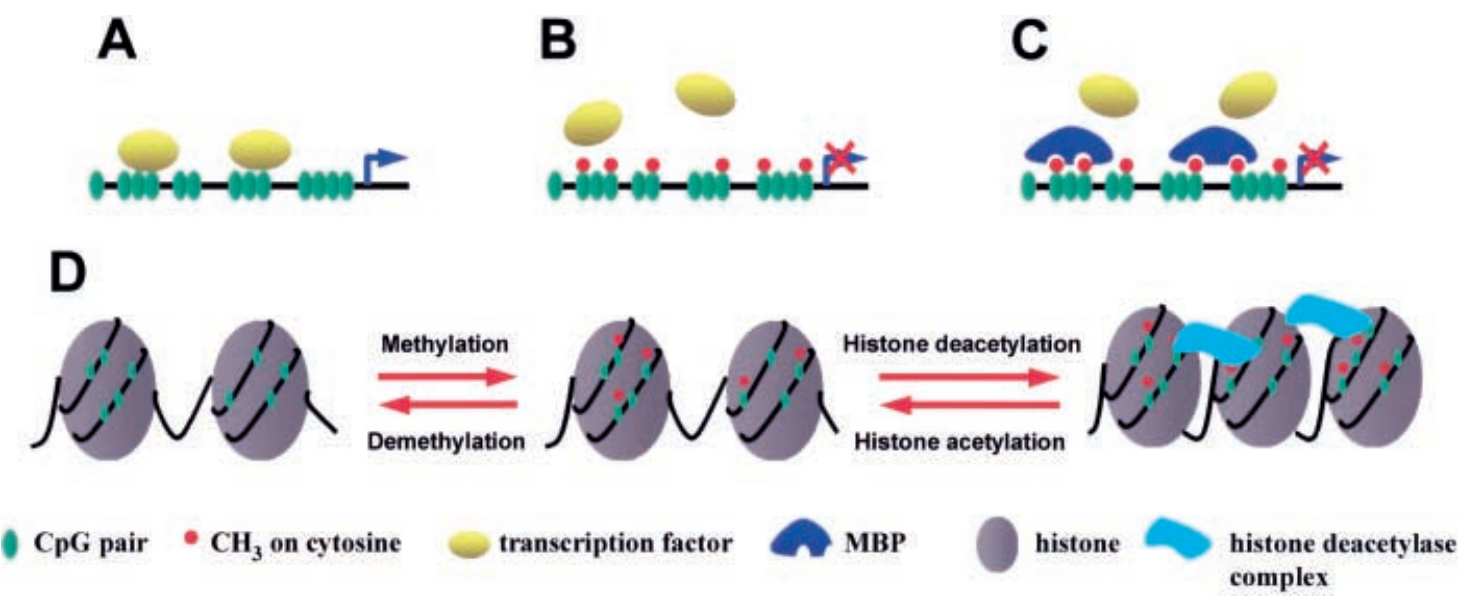

Figure 1. Mechanisms by which DNA methylation inhibits gene transcription. $(A)$ Hypomethylation of CpG dinucleotides within a promoter region allows transcription factors to bind and transcription to occur. $(B)$ Methylation of CpGs inhibits transcription factor binding and therefore gene transcription. $(C)$ The presence of methylcytosine-binding proteins (MBPs) bound to CpGs within a promoter region also blocks access of transcription factors to their binding sites. $(D)$ MBPs bound to CpGs in the promoter region form complexes with histone deacetylases and corepressors, leading to histone deacetylation, chromatin condensation and a transcriptionally inactive chromatin structure.

$\mathrm{CpG}$ islands were subsequently identified at the $5^{\prime}$ end of a number of individual genes, including murine MHC class I and II genes, as well as dihydrofolate reductase and chicken $\alpha 2$ type I collagen [7]. Similar results were obtained when restriction fragments were generated with HpaII cleavage, an enzyme whose target site contains an unmethylated CG dinucleotide. These fragments were found to be relatively unmethylated and consisted of sequences with high $\mathrm{C}+\mathrm{G}$ content (65\%), compared with bulk DNA (40\%) [8]. The increased frequency of CG pairs in $\mathrm{CpG}$ islands is reflected in the $\mathrm{CG} / \mathrm{GC}$ ratio of approximately 1 , a fivefold increase compared with 0.2 for bulk DNA [9]. The low CG/GC ratio in bulk DNA reflects the tendancy for methylcytosine to undergo deamination to thymine, which is repaired less efficiently by thymine-DNA glycosylase than the corresponding deamination of unmethylated cytosine to uracil, which is corrected by uracil-DNA glycoslyase [10].

An early indication of a relationship between $\mathrm{CpG}$ islands and the presence of genes came from restriction enzyme analysis using methylation-sensitive CG restriction enzymes [11]. Using the enzyme SacII, 3 out of $4 \mathrm{CpG}$ islands were found to be associated with active gene expression. As chromatin structure can also act as a marker for active genes, $\mathrm{CpG}$ island chromatin was compared with that of bulk chromatin and found to have significantly reduced amounts of histone $\mathrm{H} 1$, higher levels of histone $\mathrm{H} 3$ and $\mathrm{H} 4$ acetylation, and regions within $\mathrm{CpG}$ islands free of nucleosomes [12]. All these features are characteristic of transcriptionally active chromatin and further support the notion that $\mathrm{CpG}$ islands colocalize with the promoter region of active genes. This was confirmed in a comprehensive analysis of $\mathrm{CpG}$ islands in the European Molecular Biology Laboratory (EMBL) data- base [13]. Examination of 375 genes and 58 pseudogenes revealed $240 \mathrm{CpG}$ islands, virtually all of which covered part of at least one exon. More than half the genes contained $\mathrm{CpG}$ islands, and all housekeeping genes and widely expressed genes were found to have a $\mathrm{CpG}$ island covering the transcription start site [13]. It should be noted, however, that $\mathrm{CpG}$ islands do not occur exclusively within the $5^{\prime}$ region of genes but have also been identified downstream of transcription initiation sites within the transcribed region of a number of genes [14].

As noted above, most of the CG dinucleotides outside of $\mathrm{CpG}$ islands are methylated, and the large majority of these are found in transposable elements such as retrotransposons, L1 elements, Alu sequences and endogenous retroviruses, as well as juxtacentromeric satellite sequences. DNA methylation is believed to play a critical role in the suppression of parasitic and other repeat sequences (reviewed in [15-17]).

\section{The DNA methyltransferases}

DNA methyltransferase 1. Cloned in 1988, DNA methyltransferase 1 (Dnmt1) remained the only known mammalian DNA methyltransferase for 10 years [18]. Dnmt1, like bacterial methyltransferases, catalyzes the transfer of a methyl group from $S$-adenosylmethionine to the $5^{\prime}$ position on cytosine (fig. 2). The protein, 1620 amino acids long, consists of a C-terminal domain containing the catalytic site, and is more similar to bacterial DNA C5-specific restriction methyltransferases than the other more recently identified mammalian DNA methyltransferases [18]. The N-terminal region consists of multiple domains, including a nuclear localization signal, a zinc-finger 


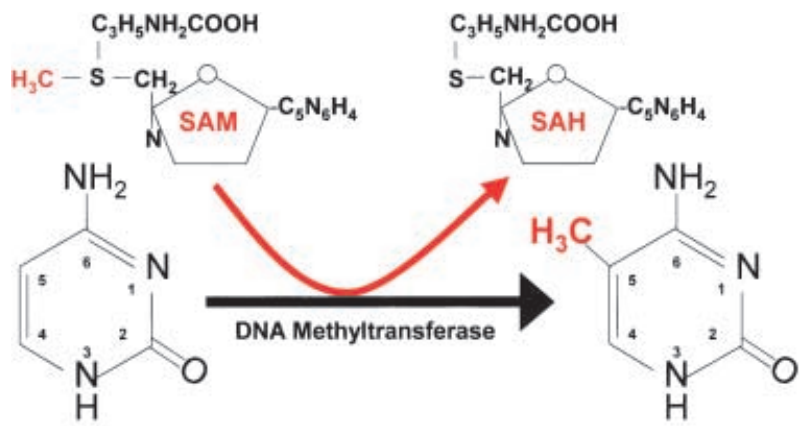

Cytosine

5-Methylcytosine

Figure 2. Formation of 5-methylcytosine. A DNA methyltransferase enzyme catalyzes the transfer of a methyl group $\left(\mathrm{CH}_{3}\right)$ from $S$-adenosylmethionine (SAM) to (deoxy)cytosine, producing 5-(deoxy)methylcytosine and S-adenosylhomocystine (SAH).

DNA binding domain [18] and a domain for targeting Dnmt1 to the replication fork during S phase [19]. DNA binding may occur through a number of domains, including the zinc binding domain, the catalytic domain and the nuclear localization sequence containing the domain [20]. However, it has also been reported that the target recognition domain for hemimethylated CG is located within the $\mathrm{N}$ terminus between amino acids 122 and 417 [21].

Our understanding of the mechanism by which methyltransferase enzymes methylate cytosine has been greatly advanced by the crystalographic analysis of the bacterial methyltransferase HhaI [22], which showed that the target cytosine is everted from the DNA helix and inserted into the active site of the enzyme. All known DNA cytosine-5-transferases contain 10 sequence motifs, with 6 being very strongly conserved [23].

Dnmt1 is believed to primarily mediate maintenance methyltransferase activity during $\mathrm{S}$ phase because of its 5-30-fold preference for hemimethylated DNA as compared with nonmethylated DNA [24]. However, there is some evidence to suggest that Dnmtl might also have de novo methyltransferase capabilities. First, an in vitro study of de novo methyltransferase activity found that all identifiable de novo activity in embryo lysates resided with Dnmt1 [24]. Second, forced overexpression of Dnmt1 led to de novo methylation in both myocytes [25] and fibroblasts [26]. Whether Dnmt1 mediates de novo methylation under normal biological conditions remains to be determined, although human immunodeficiency virus (HIV) infection was shown to result in upregulation of Dnmt1 expression and activity, resulting in de novo methylation of the interferon $\gamma$ (IFN $\gamma$ ) promoter and suppression of the IFN $\gamma$ gene [27].

Differential usage of alternative exons at the $5^{\prime}$ end of the gene gives rise to different isoforms in various tissues. In particular, the pattern of Dnmt1 expression in oocytes is quite different from that of other tissues. The oocyte-spe- cific $5^{\prime}$ exon is associated with a Dnmt1 protein that is truncated at the $\mathrm{N}$ terminus and sequestered in the cytoplasm during the later stages of oocyte growth [28]. Targeted deletion of the oocyte-specific promoter and first exon led to a loss of normal genomic imprinting [29]. By contrast, a spermatocyte-specific $5^{\prime}$ exon was shown to interfere with translation and therefore synthesis of Dnmt1 protein [28], although an identical transcript has also been identified in differentiated skeletal muscle myotubes and shown to be translated despite the presence of a number of out-of-frame upstream ATGs [30].

Targeted homozygous Dnmt1 deletion leads to embryonic lethality prior to mid-gestation [31]. Although embryonic stem (ES) cells with the targeted mutation grow normally despite markedly demethylated genomes, they undergo apoptosis when induced to differentiate [31]. However, despite Dnmt1 deletion, the ES cells retain the capacity for de novo methylation. Dnmt1 also appears to be necessary for genomic imprinting [32] and X chromosome inactivation [33].

Three recent studies have confirmed or at least supported the tendency for apoptosis to occur in differentiated cells that are completely deficient in Dnmt1. First, Cre-mediated deletion of Dnmt1 in cultured fibroblasts lead to DNA hypomethylation followed by p53-dependent apoptosis [34]. Second, Cre-mediated deletion at the CD4+ CD8+ double-positive thymocyte stage resulted in a markedly reduced number of cell cycles by stimulated naive $T$ cells, followed by growth arrest and cell death [35]. Finally, conditional Dnmt1 deletion in mitotic central nervous system (CNS) precursor cells in utero resulted in rapid elimination of mutated cells within 3 weeks of postnatal life [36].

Dnmt1 has now been shown to associate with many different proteins, including proliferating cell nuclear antigen (PCNA) [37], the transcription elongation factor $\mathrm{E} 2 \mathrm{~F} 1$, the retinoblastoma tumor suppressor protein $\mathrm{Rb}$ and the histone deacetylase HDAC1 [38]. It has also been shown to associate with a complex containing HDAC2, DMAP1, a recently identified DNMT1-binding corepressor protein, and TSG101, another corepressor [39]. De novo methylation and the methyltransferases Dnmt3a and Dnmt3b. The realization that additional DNA methyltransferases must exist arose from the observation that although Dnmt1 knockout embryos die prior to the eight-somite stage in association with widespread demethylation, Dnmt1-deficient embryonic stem cells are viable and maintain a low level of DNA methylation as well as cytosine methyltransferase activity. Furthermore, transfected proviral DNA that becomes integrated undergoes de novo methylation at the same rate as wildtype cells [40]. These findings suggested the existence of one or more de novo methyltransferases.

By screening the dbEST database with the bacterial restriction methyltransferase M.XorI, a second methyl- 
transferase, Dnmt2, was identified [41]. However, although Dnmt2 contains all 10 of the sequence motifs characteristic of DNA (cytosine-5)-methyltransferases, it lacks the N-terminal regulatory domain of other eukaryotic methyltransferases and has no detectable methyltransferase activity in vitro [42]. Furthermore, embryonic stem cells deficient for Dnmt2 display normal methylation of endogenous viral sequences as well as de novo methylation of newly integrated retroviral DNA [42]. Given that it binds strongly to DNA through a specific target-recognizing motif, Dnmt2 may identify specific sequences within the genome for some as yet unknown biological function.

With additional EST database screening using full length bacterial type II cytosine-5 methyltransferase sequences as queries, two additional DNA methyltransferases, Dnmt3a and Dnmt3b, were discovered [43]. Both enzymes are capable of methylating unmethylated and hemimethylated DNA equally in vitro [43]. Structurally, both of the Dnmt3 proteins contain a catalytic domain at the $\mathrm{C}$ terminal, an adjacent cysteine-rich domain and a variable domain at the $\mathrm{N}$ terminal. The catalytic domain of both Dnmt3a and Dnmt3b contains all of the invariant amino acids in the five highly conserved domains I, IV, VI, IX and X [44]. The cysteine-rich domain is homologous to a similar domain in the X-linked ATRX gene of the SNF2/SW1 family that is known to mediate its association with the histone deacetylase HDAC1 [45].

Although Dnmt1 possesses de novo methylation activity in vitro, targeted deletion of either of the Dnmt3 genes has confirmed the essential requirement of Dnmt3a or Dnmt3b for de novo methylation in vivo [46]. Methylation of a recombinant retrovirus transfected into ES cells required either Dnmt3a or Dnmt3b, but not both, indicating redundancy of de novo methylation function. Although Dnmt3a knockout mice appeared normal at birth, most became runted and died at about 4 weeks of age. Dnmt3b embryos, however, died in utero from multiple developmental defects. Endogenous C-type retroviral DNA was normally methylated in Dnmt3a knockout mice and slightly undermethylated in Dnmt3b knockout mice. However, double-knockout mice demonstrated marked hypomethylation of these endogenous retroviral sequences. Examination of the role of Dnmt3a and Dnmt3b in the methylation of imprinted genes produced mixed results. Whereas the methylation status of the region 2 intronic $\mathrm{CpG}$ island of Igf $2 \mathrm{r}$ and the $5^{\prime}$ upstream region of H19 was unchanged in double-knockout ES cells, almost complete demethylation of DMR2, another region of the Igf2r gene, occurred in the same cells. Finally, a unique role for Dnmt3b in the methylation of juxtacentromeric minor satellite repeats was revealed in ES cells from the Dnmt3b knockout, which had substantially hypomethylated satellite repeats. This is consistent with the association of Dnmt3b mutations and the congenital disease ICF (see below). Although the studies on de novo methylation of transfected retroviruses suggested redundancy of function of Dnmt3a and Dnmt3b, their unique patterns of tissue expression in the embryo suggest that they have separate functions.

The demonstration of physiological de novo methylation activity has largely been confined to the postimplantation embryo and primordial germ cells of midgestation embryos. With the exception of de novo methylation of the CD8 coreceptor gene [47], there is no evidence to date that de novo methylation plays a significant role in the normal regulation of gene expression apart from embryonic tissues. Similarly, little is known regarding the functions of the de novo methyltransferases in nonembryonic tissues. However, expression of Dnmt3a and $3 b$ has been shown in various adult tissues [43, 48], and it is reasonable to suggest that there may be de novo methyltransferase activity occuring in these tissues. We have identified upregulation of both Dnmt3a and Dnmt3b during the early stages of $\mathrm{T}$ cell activation [authors' unpublished data]. Dnmt3a has recently been shown to associate with RP58, a DNA-binding protein with transcriptional repressor activity, and also with HDAC1 via its ATRXhomologous domain. Furthermore, Dnmt3a was shown to act as a corepressor with RP58, independent of its methyltransferase activity [45]

DNA demethylation. Very little is known about the process of genomic demethylation. That it occurs at all is clearly demonstrated in the developing embryo, in which a wave of demethylation following fertilization leads to an almost complete conversion of methylcytosines to cytosines [49, 50]. However, demethylation of DNA in adult tissue is poorly characterized and with few exceptions has not yet been clearly demonstrated in normal cells. The generally accepted view is that demethylation occurs during development when gene expression patterns in somatic cells are being laid down and genes become activated in a cell-type specific fashion. Excluding embryonic studies, most evidence for demethylation events comes from analysis of transfected genes [51]. In addition, a global loss of methylcytosines occur in many tumors as well as with ageing, as will be discussed later. Demethylation of genomic DNA can occur in two ways. First, passive demethylation occurs only in the context of DNA replication. This is thought to be the primary mechanism of demethylation mediated by cytosine analogs such as 5-azacytidine. It has been suggested that certain DNA-binding factors may block cytosine methylation that normally occurs during $\mathrm{S}$ phase [52].

The second mechanism occurs independent of DNA synthesis, and involves the action of demethylases. The first evidence for demethylase activity occurred with the demonstration of demethylation activity in nuclear extracts of chicken embroyos [53]. Demethylation was shown to occur through nucleotide excision repair of 5- 
methyldeoxycytidine. Subesequently, the protein responsible for this activity was identified as 5-methylcytosine DNA glycosylase (5-MCDG) [54] and found to require RNA for its demethylating function [55]. Both enzyme and RNA appear to exist in a larger complex that also contains an RNA helicase and the G/T mismatch DNA glycosylase [56]. The RNA may play a role in recognition of methylated CG dinucleotides. When overexpressed in human embryonic kidney cells, 5-MCDG has recently been shown to specifically demethylate a stably integrated ecdysone-retinoic acid responsive enhancer-promoter [57]. Whether the function of 5-MCDG is primarily that of a demethylase rather than a DNA repair enzyme remains to be elucidated.

One of the methylcytosine binding proteins, MBD4, has also been shown to act as a demethylase with similar 5methylcytosine glycosylase activity [58]. Although another methylcytosine-binding protein, MDB2, has been shown to have demethylase activity, catalyzing the direct reaction of the 5-methylcytosine moiety with water to form cytosine and methanol [59], this has not been confirmed by others $[60,61]$ (see below for further discussion of MBD2 and MBD4).

\section{Relationship between DNA methylation and gene expression}

Tissue-specific gene methylation. A role for DNA methylation in gene regulation was first proposed in the 1970s [62, 63], and supporting evidence has accumulated over the intervening years. Most of the early data was correlative. Methylation of the rabbit $\beta$ globin gene [64] and subsequently other genes was noted to occur in a tissue-specific pattern, consistent with a role of methylation in tissue-specific gene regulation. Further studies on the tissue-specific expression of the chicken $\beta$ globin [65] and ovalbumin [66] genes as well as the human $\beta$ globin locus [67] demonstrated a positive correlation between hypomethylation and gene expression in different tissues. Cytosine analogs. Evidence has also come from the use of DNA methyltransferase inhibitors such as the cytosine analogs 5-azacytidine and 5-aza-2'-deoxycytidine. The earliest experiments involved treatment of mouse embryonic cells with 5-azacytidine, which gave rise to differentiated phenotypes, including muscle cells, adipocytes and chondrocytes [68]. These changes were subsequently shown to be associated with DNA hypomethylation [69]. DNA substituted with 5-azacytidine covalently binds DNA methyltransferase enzymes, leading to loss of activity and DNA hypomethylation [70]. However, the cytotoxicity of these cytosine analogs may be independent of their ability to cause DNA hypomethylation, as mice partially deficient in DNA methyltransferase activity are actually more resistant to the cytotoxic effects of 5-aza- 2'-deoxycytidine [71]. Since the original experiments with mouse embryonic cells, there have been numerous reports of the induction of new cellular phenotypes in response to treatment with cytosine analogs (reviewed in [72]), although the known inhibitory effects of these agents on cell division may have contributed to the observed phenotypic changes [73, 74]. Induction of specific gene expression by 5 -azacytidine treatment was first reported for the HGPRT gene located on the inactive $\mathrm{X}$ chromosome [75]. This report also lead to an understanding of the fundamental role that DNA methylation plays in X chromosome inactivation. Upregulation of perhaps many hundreds if not thousands of genes secondary to cytosine analog treatment have since been reported (early experiments are reviewed in [72]).

Genomic imprinting and $\mathrm{X}$ chromosome inactivation. In vivo evidence for the involvement of DNA methylation in gene regulation is found in the biological phenomena of genomic imprinting and $\mathrm{X}$ chromosome inactivation. In both, gene silencing is strongly associated with hypermethylation of $\mathrm{CpG}$ islands within the promoter region of silenced genes. Genomic imprinting is a process whereby only one of the two parental alleles is expressed, whereas the other gene is imprinted or silenced by DNA methylation (reviewed in [76-80]). Imprinted genes are germline derived and inherited from either the maternal or paternal gamete. About 45 imprinted genes have been identified in the mouse, and $\sim 88 \%$ have $\mathrm{CpG}$ islands [81]. By generating uniparental mouse embryonic fibroblasts and treating with DNA methylation inhibitors, it was possible to induce expression of some but not all imprinted genes [82]. However, the mechanism of imprinting is quite complex and, in addition to $\mathrm{CpG}$ island methylation, involves insulator or boundary elements, repressor proteins such as CTCF and antisense transcripts (reviewed in [80, 83-86]). Nevertheless, DNA methylation appears to play a critical role in the regulation of these processes as well. The functional significance of genomic imprinting is unclear, but, as hypothesized in the 'conflict theory', may be a genetic mechanism to balance the in utero growth requirements of the developing fetus versus the health of the mother [87-90].

$\mathrm{X}$ chromosome inactivation is a related methylation-dependent phenomenon and consists of the transcriptional silencing of one of the two X chromosomes in mammalian females. This is to ensure equivalent levels of gene expression from the sex chromosomes in both males and females, i.e. gene dosage compensation (reviewed in [91-94]).

Transfection of differentially methylated genes (patch methylation). Although it has been possible to pharmacologically demethylate CG dinucleotides in DNA of cultured cells, pharmacological methylation of specific unmethylated CGs in vivo has not been feasible to date. One experimental approach used to overcome this problem is 
the methylation of genes in vitro using bacterial methyltransferases and their transfection back into cells. An early example is the in vitro methylation of the hamster adenine phosphoribosyltransferase (aprt) gene at all CCGG sites with HpaII methylase and its subsequent transfection into murine L cells. Compared with cells transfected with the nonmethylated gene, methylation inhibited aprt expression [95]. Similarly, in vitro methylation of the human $\gamma$ globin gene in its $5^{\prime}$ region but not elsewhere inhibited its expression following transfection into mouse L cells [96]. Many similar experiments have now been performed, demonstrating a suppressive effect of DNA methylation on transfected genes. Recently, a more physiological approach was achieved by creating a transgenic mouse containing a 120-bp island element (IE) sequence that consisted of two $\mathrm{Sp} 1$ sites from the hamster aprt $\mathrm{CpG}$ island [97]. This sequence was able to protect itself and also CG dinucleotides up to $150 \mathrm{bp}$ away from de novo methylation. By creating a loxPflanked version of this sequence, it was possible to generate Cre-mediated deletion at either the preimplantation stage before the normal wave of de novo methylation had taken place, or later in the adult mouse. With the IE placed within a reporter gene, it was possible to show that Cre-mediated deletion prior to the wave of de novo methylation lead to persistent methylation and suppressed expression of the reporter construct, whereas deletion in the adult mouse did not lead to further methylation [97].

\section{Mechanisms by which DNA methylation regulates gene expression}

Direct inhibition of transcription factor binding. DNA methylation may suppress gene transcription in two general ways (fig. 1). First, methylated CG dinucleotides may directly interfere with the binding of transcription factors to their recognition sequences, presumably by protruding into the major DNA groove. The movement of RNA polymerase along the gene does not seem to be affected by methylation, because coding regions downstream of the promoter usually contain CG dinucleotides that are mostly methylated. This suggests that for methylated CG dinucleotides to directly inhibit transcription, they must lie in or near promoter sites or other cis-acting regulatory elements. This has been demonstrated for the binding of AP-2 to its recognition sequence within the promoter site of the proencephalin gene. Methylation of a CCGG site within the AP-2 binding sequence inhibited binding of AP-2 and is thought to explain the inhibition of expression of a proenkephalin-CAT fusion gene methylated at CCGG sites [98]. Similar inhibition has been demonstrated for the binding of ATF/CREB to the cyclic AMP (cAMP)-responsive element [99] and c-Myc to its regulatory element [100]. However, although Sp1 binding has also been shown to be inhibited by DNA methylation [101], the presence of methylated CG within its recognition sequence did not prevent its binding to a synthetic oligonucleotide containing this methylated recognition sequence [102]. In addition to this direct interference by methylated cytosines with the binding of transcripton factors to DNA, methylcytosine binding proteins can also prevent the binding of transcription factors to their promoter sequences [103].

Methylcytosine-binding proteins, histone deacetylase complexes and indirect inhibition of transcription factor binding. Second, regions of methylated DNA adjacent to the promoter sites of genes may recruit methylcytosinebinding proteins (see table 1) that in turn associate with large protein complexes containing corepressors and histone deacetylases. The binding of these complexes to DNA leads to a change in the chromatin structure from an active to an inactive form. The best-characterized methylcytosine-binding protein is $\mathrm{MeCP} 2$, identified by its ability to bind to DNA containing as little as a single methylated CG dinucleotide [104]. MeCP2 contains a methylCG binding region within an 85-amino acid domain near the $\mathrm{N}$ terminus [105] as well as a transcriptional-repression domain between amino acids 221 and 249 [106]. $\mathrm{MeCP} 2$ is concentrated in juxtacentromeric heterochromatin that contains a large fraction of all genomic methylcytosine [104, 107]. Murine MeCP2 associates with the Sin 3 A histone deacetylase complex, consisting of at least seven proteins including the transcriptional repressor $\operatorname{Sin} 3 \mathrm{~A}$ and histone deacetylases HDAC1 and HDAC2 [108], thus linking DNA methylation with histone deacetylation. Histone deacetylation suppresses gene expression by removing acetyl groups from histones, which in turn leads to more compact chromatin that is transcriptionally inactive (reviewed in [109]). A similar association occurs between homologous proteins in Xenopus laevis oocytes [110]. However, transcriptional repression by MeCP2 may also occur independent of histone deacetylases [103], suggesting that $\mathrm{MeCP} 2$ may directly compete with transcription factors, thereby preventing gene expression. Because of the abundance of methylated CG dinucleotides within the genome, MeCP2 may act as a global transcriptional repressor [106].

Two additional histone deacetylase complexes have been identified. These include MeCP1 [60, 111], which contains the methyl-CpG binding domain protein 2 (MBD2), the histone deacetylases HDAC1 and HDAC2, and the retinoblastoma protein-binding proteins $\mathrm{RbAp} 46$ and RbAp48 (also present in the Sin3A histone deacetylase complex). The latter were previously shown to copurify with histone deacetylases and may mediate core-histone binding of the histone deacetylase complex. The second histone deacetylase complex is the Mi-2 (or NuRD) complex that contains at least seven proteins, including Mi-2, 
Table 1. DNA Methyltransferases and Methylcytosine-Binding Proteins.

\begin{tabular}{|c|c|c|c|}
\hline Protein & Function & Binding Site & Deficiency/Disease States \\
\hline \multicolumn{4}{|c|}{ 1. DNA Methyltransferases } \\
\hline Dnmt1 & $\begin{array}{l}\text { Maintenance of DNA methylation pattern } \\
\text { during S phase. De novo methylation } \\
\text { in vitro. Methylation independent in- } \\
\text { hibition of gene transcription in vitro }\end{array}$ & DNA replication foci & $\begin{array}{l}\text { Embryo-lethal in muring knockout. } \\
\text { SLE associated with reduced levels. }\end{array}$ \\
\hline Dnmt2 & $\begin{array}{l}\text { Unknown. No detectable DNA } \\
\text { methyltransferase activity in vitro }\end{array}$ & unknown & $\begin{array}{l}\text { Normal phenotype of knockout ES } \\
\text { cells. No known human deficiency. }\end{array}$ \\
\hline Dnmt3a & $\begin{array}{l}\text { De novo methylation in vivo (lost in } \\
\text { Dnmt3a/3b double-knockout embryo) } \\
\text { and in vitro. Methylation-independent } \\
\text { inhibition of gene transcription in vitro }\end{array}$ & $\begin{array}{l}\text { pericentromeric DNA } \\
\text { and elsewhere in the } \\
\text { nucleus }\end{array}$ & $\begin{array}{l}\text { Death at about } 4 \text { weeks in murine } \\
\text { knockout. No known human } \\
\text { deficiency. Possible involvement in } \\
\text { promoter hypermethylation in tumors. }\end{array}$ \\
\hline Dnmt3b & $\begin{array}{l}\text { De novo methlation in vivo (lost in } \\
\text { Dnmt3a/3b double-knockout embryo). } \\
\text { Methylation of pericentromeric } \\
\text { DNA satellite repeats. Methylation- } \\
\text { independent inhibition of gene } \\
\text { transcription in vitro }\end{array}$ & $\begin{array}{l}\text { pericentromeric DNA } \\
\text { and elsewhere in the nucleus }\end{array}$ & $\begin{array}{l}\text { Embryo-lethal in murine knockout. } \\
\text { ICF syndrome associated with } \\
\text { mutations in DNMT3b in humans. } \\
\text { Possible involvement in promoter } \\
\text { hypermethylation in tumors. }\end{array}$ \\
\hline \multicolumn{4}{|c|}{ 2. Methylcytosine-Binding-Proteins } \\
\hline $\mathrm{MeCP} 2$ & $\begin{array}{l}\text { Suppression of gene expression in vitro } \\
\text { and in vivo, both alone and in conjunction } \\
\text { with Sin } 3 \text { A histone deacetylase complexes. } \\
\text { May act as global suppressor of gene } \\
\text { expression }\end{array}$ & $\begin{array}{l}\text { methylated DNA; Peri- } \\
\text { centromeric satellite DNA } \\
\text { especially rich in MeCP2; } \\
\text { may require as many as } \\
10 \text { CpGs for bindung }\end{array}$ & $\begin{array}{l}\text { Neurological abnormalities in } \\
\text { various murine knockout models. } \\
\text { Rett syndrome and X-linked } \\
\text { mental retardation associated with } \\
\text { mutations in MeCP2 in human }\end{array}$ \\
\hline MBD1 & $\begin{array}{l}\text { Suppression of gene expression. } \\
\text { Probably associated with as yet } \\
\text { unidentified histone deacetylases. }\end{array}$ & $\begin{array}{l}\text { methylated DNA, especially } \\
\text { pericentromeric satellite DNA; } \\
\text { may require only a single } \\
\text { CpG dinucleotide for binding }\end{array}$ & $\begin{array}{l}\text { No published murine knockout. } \\
\text { No known human deficiency. }\end{array}$ \\
\hline MBD2 & $\begin{array}{l}\text { Suppression of gene expression. } \\
\text { Associated with MeCP1, Sin } 3 \mathrm{~A} \\
\text { and Mi2/NuRD histone deacetylase } \\
\text { complexes. One report of demethylase } \\
\text { activity, but not reproducible by others. }\end{array}$ & $\begin{array}{l}\text { Methylated DNA, especially } \\
\text { pericentromeric satellite DNA }\end{array}$ & $\begin{array}{l}\text { Abnormal maternal behavior in } \\
\text { murine knockout. No known } \\
\text { human deficiency. }\end{array}$ \\
\hline MBD3 & $\begin{array}{l}\text { Suppression of gene expression. } \\
\text { Associated with Mi2/NuRD } \\
\text { histone deacetylase complex. }\end{array}$ & $\begin{array}{l}\text { nuclear foci, but apparently } \\
\text { not methylated DNA }\end{array}$ & $\begin{array}{l}\text { Embryo-lethal in murine knockout. } \\
\text { No known human deficiency. }\end{array}$ \\
\hline MBD4 & $\begin{array}{l}\text { G/T mismatch and 5-methycytosine } \\
\text { DNA glycosylase activity. Possibly } \\
\text { involved in DNA demethylation. }\end{array}$ & $\begin{array}{l}\text { methylated DNA, especially } \\
\text { pericentromeric satellite DNA }\end{array}$ & $\begin{array}{l}\text { No published murine knockout. No } \\
\text { known human deficiency. Possible } \\
\text { tumor suppressor gene, mutated in } \\
\text { some colorectal carcinomas. }\end{array}$ \\
\hline
\end{tabular}

a protein believed to have chromatin remodeling activity, HDAC1, HDAC2, RbAp46, RbAp48 and also the methylcytosine-binding protein MBD3 [112]. Interestingly, MBD2 has been found in association with both Sin3A [113] and also the Mi2/NuRD complex [112], and is likely to play a role in gene repression mediated by both $\operatorname{Sin} 3 \mathrm{~A}$ and the Mi2/NuRD histone deacetylase complexes.

Dnmt 1 has also been identified in a complex that contains both $\mathrm{Mbd} 2$ and $\mathrm{Mbd} 3$, binds to hemimethylated DNA and is located at the replication focus during late $\mathrm{S}$ phase [114]. The genes for both Mbd2 and Mbd3 have very recently undergone targeted deletion [115]. Mbd3 knockout mice die during early embryogenesis, whereas Mbd2 knockout mice appear to be largely normal except for defective maternal behavior.
In addition to MBD2 and MBD3, the MBD family of methylcytosine-binding proteins includes two further members, MBD1 and MBD4 [116, 117]. MBD1 contains a transcriptional repression domain, binds to methylcytosine-containing DNA and suppresses gene transcription at a distance from its binding site. Its ability to suppress transcription is overcome by the histone deacetylase inhibitor trichostatin $\mathrm{A}$, indicating the involvement of deacetylases in gene suppression mediated by MBD1. However, MBD1 does not appear to associate with HDAC1 as do MeCP2, MBD2 and MBD3, suggesting it may differ in its mode of action [118]. Unlike the other MBD family members, MBD4 does not suppress gene transcription but functions as a $\mathrm{G} / \mathrm{T}$ mismatch glycosylase activity as well as having 5-methylcytosine DNA glycosylase activity [119]. 


\section{DNA methylation and the regulation of immune system genes}

INFy and other cytokine genes. Increasing evidence has emerged in recent years for a prominent role of epigenetic regulation, including DNA methylation, of immune system genes. Much effort has focused on the regulation of cytokine gene expression in the context of T-helper-cell subset generation and in particular the IFN $\gamma$ gene (reviewed in [120]). An early indication of the importance of DNA methylation in IFN $\gamma$ regulation was the finding that CG dinucleotides close to or within the gene were relatively hypomethylated in $\mathrm{T}$ cells relative to other tissues and cell lines [121]. Further, levels of IFN $\gamma$ expression correlated inversely with the degree of DNA methylation in a number of T cell lines [121]. Expression of IFN $\gamma$ was subsequently confirmed to correlate with the presence or absence of methylation of a CG dinucleotide within a TATA proximal regulatory element of the IFN $\gamma$ promoter region, with almost complete methylation of this site occuring in nonexpressing Th2 clones but partial or complete hypomethylation in Th1 clones, which express this gene. In addition, treatment of human Th2 clones with 5azacytidine induced IFN $\gamma$ production [122]. Methylation analysis of three CG sites within the $5^{\prime}$-flanking region and first intron of the IFN $\gamma$ gene revealed that thymocytes, neonatal $\mathrm{T}$ cells and naive adult $\mathrm{T}$ cells had an almost completely methylated IFN $\gamma$ gene. This was in contrast to the relatively hypomethylated state of the IFN $\gamma$ gene of $\mathrm{T}$ cell lines that expressed IFN $\gamma$ at high levels [123]. A regulatory element within the IFN $\gamma$ promoter determining tissue-specific expression contains a CG dinucleotide that is selectively methylated in Th2 cells and other cell types that do not express IFN $\gamma$ [124]. In addition, methylation of this $\mathrm{CG}$ dinucleotide reduced binding of the transcription factors CREB, ATF-2 and Jun [124]. After TCR ligation, human naive CD4 T cells secreted IFN $\gamma$ and coincidentally partially demethylated a CG dinucleotide with the TATA proximal regulatory element [125]. Interestingly, both the upregulation of IFN $\gamma$ secretion and the associated CG demethylation were inhibited by prostaglandin $\mathrm{E}$ and interleukin (IL)-4. Increased IFN $\gamma$ gene methylation and the associated decreased expression have also been observed in CD4 T cells from tumor-bearing mice in response to treatment with phosphatidyl serine [126].

Analogous to T-cell-activation-related decreases in IFN $\gamma$ promoter methylation, demethylation of $\mathrm{CG}$ dinucleotides within the IL-4 promoter have also been shown to occur concomitantly with $\mathrm{T}$ cell activation under Th2but not Th1-polarizing conditions [127]. Comparison of D5 and D10, Th1 and Th2 clones respectively, also revealed differential demethylation of the IL-4 locus in D10 cells associated with Il-4 secretion [127]. Treating naive $\mathrm{T}$ cells with 5-aza-2-deoxycytidine under nonpolarizing conditions led to significantly increased numbers of IL4-positive cells (as well as increased IFN $\gamma$-positive cells) in a cell-cycle-dependent fashion [128]. Both the IL-4 and IL-5 loci were found to be differentially demethylated in a Th $2 \mathrm{~T}$ cell clone as compared with a Th1 clone. Detailed kinetic analysis demonstrated IL-4 locus demethylation between days 4 and 7 following Th2 priming [128]. In fact, coordinate chromatin remodeling appears to occur within the whole IL-4/IL-5/IL-13 gene cluster with Th2 polarization of naive $\mathrm{T}$ cells, although the role of DNA methylation in this process remains to be determined $[127,129]$.

Finally, demethylation of CG sites within the IL-3 promoter occurs in activated CD8+ $\mathrm{T}$ cell clones, with most of the demethylation occuring at a specific CG dinucleotide $164 \mathrm{bp}$ upstream of the transcriptional start site [130].

CD4 and CD8 coreceptor genes. Regulation of CD4 and CD8 coreceptor gene expression has also been associated with CG methylation. Early work from our lab demonstrated the induction of $\mathrm{CD} 4$ expression in $\mathrm{CD} 8+\mathrm{T}$ cells treated with the DNA methyltransferase inhibitor 5-azacytidine [131]. Analysis of CD8 gene methylation status in thymocytes revealed progressive demethylation during the transition from CD4-CD8- single-positive to CD4+CD8+ double-positive thymocytes [132]. Similar demethylation was observed in the CD4 gene locus during thymocyte maturation from $\mathrm{CD} 4-\mathrm{CD} 8$ - double-negative cells through $\mathrm{CD} 4+\mathrm{CD} 8+$ double-positive, $\mathrm{CD} 4+$ single-positive thymocytes and finally $\mathrm{CD} 4+$ peripheral $\mathrm{T}$ cells [133]. CD8 gene expression in a CD4+CD8+ T cell derivative of a $\mathrm{CD} 4+\mathrm{CD} 8-\mathrm{T}$ cell line was associated with demethylation at a number of sites within the CD8 gene [134]. Examination of the $\mathrm{CD} 8 \beta$ gene $5^{\prime}$ regulatory region has also identified CG dinucleotides that are differentially demethylated in $\mathrm{CD} 8 \beta$-expressing thymocytes and peripheral T cells [135]. Recently, it was noted that continued CD8 expression is required for survival of peripheral CD8+ $\mathrm{T}$ cells. In the absence of engagement of both the $\mathrm{T}$ cell receptor and $\mathrm{CD} 8$ coreceptor, $\mathrm{CD} 8 \alpha$ downregulation occurs by de novo methylation of the $\mathrm{CD} 8 \alpha$ gene and subsequent apoptosis through a Fas-Fas ligand interaction [47]. An earlier study also reported the occurrence of de novo methylation in association with $\mathrm{CD} 8 \alpha$ downregulation in a T cell hybridoma [136].

Major histocompatibility complex genes. A role for DNA methylation in the regulation of $\mathrm{MHC}$ gene expression is more controversial, with evidence both for and against. In the case of the class II trans-activator (CIITA) gene, there is good evidence that CG methylation within its IFN $\gamma$-inducible promoter IV is important in suppressing IFN $\gamma$-inducible CIITA expression and therefore also the expression of major histocompatibility (MHC) class II genes in normal trophoblastic cells, which downregulate MHC expression in general to avoid immune recognition [137, 
138]. As CIITA is also involved in the regulation of MHC class I genes, it is possible that methylation-induced suppression of CIITA expression may also lead to MHC class I gene downregulation in some tissues. As for the MHC class II genes themselves, there is some evidence that, at least in the case of the HLA-DR $\alpha$ gene, extensive methylation did not prevent transcription [139], and analysis of various melanoma cell lines treated with IFN $\gamma[140]$ as well as other mononuclear cell lines [141] demonstrated no correlation between human leukocyte antigen (HLA)DR gene expression and levels of methylation. In fact, early analysis of melanoma and other cell lines unexpectedly found an positive correlation between HLA-DR $\alpha$ gene methylation levels and gene expression $[142,143]$. Most MHC class I genes are associated with hypomethylated $\mathrm{CpG}$ islands [144].

Although methylation of murine class I genes has been described, this has also been in the context of increased rather than reduced expression of the methylated gene $[145,146]$. Similarly, whereas MHC class I expression is suppressed in trophoblastic tissue, there is no evidence that any of the MHC class I genes are methylated [147]. Further research on the issue of DNA methylation and MHC gene regulation would help clarify these issues, particularly as much of the research is not of recent origin.

$\mathrm{T}$ - and B-cell-receptor gene rearrangement. Another area of epigenetic immune gene regulation that has recently attracted considerable attention is the control of recombination events during the somatic rearrangement of $\mathrm{T}$ - and B-cell-receptor gene segments (reviewed in [148]). An early indication for a possible role of DNA methylation in antigen receptor regulation was the finding that the $\mathrm{J}$ chain gene was heavily methylated in B cell lines not expressing the $\mathrm{J}$ chain, whereas cell lines expressing the protein contained hypomethylated J chain genes [149]. Further work on B cells found that the degree of heavychain gene methylation correlated inversely with level of expression. In addition, all immunoglobulin loci were found to become increasingly demethylated with increasing B cell maturity [150].

Subsequent studies on the T cell receptor (TCR) demonstrated that the rearranged TCR- $\beta$-chain gene was highly unmethylated in mature peripheral blood $\mathrm{T}$ cells compared with nonexpressing B cells and monocytes [151] Further research by the same group demonstrated that the TCR- $\beta$-chain region was hypomethylated in either CD4+ or $\mathrm{CD} 8+$ single-positive murine thymocytes as compared with the less mature CD4-CD8- subset, whereas the same region was heavily methylated in macrophages [152]. Analysis of TCR methylation changes using methylation-sensitive enzymes has confirmed demethylation of the TCR- $\beta$ locus during CD4-CD8- to CD4+CD8+ thymocyte differentiation [153]. In addition, studies on the locus control region (LCR) for the TCR- $\alpha / \delta$ locus using germline deletions of two DNase I-hypersensitivity site clusters within the LCR suggest that these elements may mediate directed demethylation of a localized region within the LCR itself [154].

Deletion of the TCR- $\beta$ enhancer leads to persistence of methylation within $\mathrm{D} \beta-\mathrm{J} \beta$ clusters which normally become demethylated in developing thymocytes [155]. Finally, another mouse model containing deletion of the germline transcriptional promoter $\operatorname{PD} \beta 1$ also demonstrates DNA hypermethylation in the $\mathrm{D} \beta 1-\mathrm{J} \beta 1$ region and reduced $\mathrm{D} \beta 1$ rearrangement compared with normal mice [156]. In this case, methylation of a specific CG dinucleotide within one of the recombination signal sequences completely blocked the cleavage which would normally occur during VDJ recombination.

\section{DNA methylation and disease states}

Inherited disorders of methylation. With the increasing numbers of proteins known to be involved in the methylation process, it is not surprising that a number of genetic disorders have now been linked to congenital deficiencies of some of these proteins. Characteristic developmental abnormalities are a prominent feature of most of these disorders.

The ICF syndrome (immunodeficiency, centromere instability and facial anomalies) is a rare autosomal recessive disorder characterized by facial abnormalities, mental retardation and immunoglobulin deficiencies [157]. Lymphocytes from ICF patients demonstrate cytogenetic abnormalities, primarily localized to the juxtacentromeric regions of chromosomes 1, 9 and 16. Somewhat similar changes are seen when normal cells are treated with the demethylating agent 5-azacytidine [158]. These chromosomal regions are rich in tracts of classical satellites 2 and 3, which are usually heavily methylated, but are markedly hypomethylated in the ICF syndrome [159]. This disorder is now known to be associated with mutations in Dnmt3b [46, 160] and is consistent with Dnmt3b's known role in methylating juxtacentromeric satellite repeats [46]. None of the mutations leads to complete absence of the enzyme, a condition that is lethal in embryonic dnmt3b-deficient mice [46].

Another inherited condition, Rett syndrome, is one of the most common causes of female mental retardation [161]. Affected girls usually have no phenotype until 6-18 months of age, when they gradually lose speech and purposeful hand use and develop microencephaly, seizures, ataxia, episodes of hyperventilation and stereotypic hand movements. Mutations in the methylcytosine-binding protein $\mathrm{MeCP} 2$ are now known to occur in individuals with Rett syndrome [162]. The strongly neurodevelopmental nature of this disorder is consistent with the normally high levels of $\mathrm{MeCP} 2$ expression found in the 
brain. Recently, MeCP2 knockout mice have been generated by targeted deletion [163, 164]. These mice develop severe neurological symptoms by about 6 weeks old, and heterozygous females also demonstrate abnormal behavior after several months. It is postulated that $\mathrm{MeCP} 2$ is involved in maintaining the stability of brain function rather than brain development [163].

A third condition associated with dysregulation of methylation is the ATR-X syndrome, characterized by severe, $\mathrm{X}$-linked mental retardation, facial dysmorphism, urogenital abnormalities and alpha-thalassemia [165]. ATRX is a member of the SNF2 family, whose members all have similar adenosine triphosphate (ATP)ase and helicase domains. ATRX is localized to pericentromeric heterochromatin during interphase and mitosis. Mutations in the ATRX gene have been shown to be associated with alterations in the methylation patterns of a number of highly repeated sequences, including hypomethylation of ribosomal DNA arrays, hypermethylation of the Y-specific repeat DYZ2 and other subtle changes in subtelomeric repeats [166].

Defects in the imprinting process occurs in a number of developmental disorders, including Prader-Willi syndrome; the related disorder, Angelman's syndrome; and Beckwith-Wiedemann syndrome [167]. Prader-Willi syndrome is characterized by mild-to-moderate mental retardation associated with neonatal hypotonia, hypogonadism, short stature secondary to reduced growth hormone secretion, facial dysmorphia and hyperphagia [168]. The condition results from lack of transcripts expressed from the paternal copy of the imprinted chromosomal region 15q11-q13 [169]. Angelman syndrome is a similar disorder in which a deletion has occurred in the same region of chromosome 15 but on the maternal chromosome [169]. Beckwith-Wiedemann syndrome is an overgrowth condition associated with various abnormalities of the chromosome $11 \mathrm{p} 15$ region, a region that is known to be subject to genomic imprinting. One result is the overexpression of insulin-like growth factor 2 (IGF2) that may in part be responsible for the overgrowth [170, 171].

Finally, a number disorders arise from the expansion of trinucleotide repeats within genes. Fragile $\mathrm{X}$ syndrome, a common form of inherited mental retardation, is one such disorder and is associated with marked expansion of a CCG triplet within the $5^{\prime}$-untranslated region of the FMR1 gene on the $\mathrm{X}$ chromosome [172]. Such expansion occurs in germ cells and gives rise to 'anticipation' in succeeding families. The silencing of the FMR1 gene appears to occur via methylation of the expanded trinucleotide repeat as well as a $\mathrm{CpG}$ island within the promoter region of the gene itself, with associated histone deacetylation leading to absence of FMR1 protein [173]. Methylation and autoimmune disease. There have been few studies into the role of abnormal DNA methylation in diseases apart from cancer. Systemic lupus erythematosus (SLE) is an autoimmune disease that primarily effects women and is characterized by increased antibody production and abnormalities in T cell function. The hypothesis that $\mathrm{T}$ cell DNA hypomethylation might be a factor in the etiopathogenesis of SLE originally arose from the observation in our lab that $\mathrm{CD} 4+\mathrm{T}$ cells treated with 5-azacytidine become autoreactive and respond to autologous macrophages without the need for antigen [174]. In addition, 5-azacytidine-treated CD4+ T cells induce autologous $\mathrm{B}$ cell differentiation in the absence of any requirement for exogenous antigen [175]. The autoreactivity is due in part to the overexpression of the adhesion molecule LFA-1 (CD11a/CD18), since causing LFA-1 overexpression by transfection causes an identical autoreactivity [176]. Because of the known relationship between hydralazine and procainamide and the development of SLE, these drugs were investigated for their effects on DNA methylation, and found to inhibit DNA methylation as well as induce LFA-1 overexpression and autoreactivity in CD4+ T cells [177].

These observations led to the question whether DNA hypomethylation might be associated with human SLE and other autoimmune diseases. Supporting evidence arose from studies of SLE and rheumatoid arthritis patients which demonstrated hypomethylated DNA in T cells from these patients as compared with normal controls [178]. These findings were confirmed by another group [179]. Further evidence supporting an etiologic role for $\mathrm{T}$ cell DNA hypomethylation in autoimmunity came from studies in which stimulated murine CD4+ T cells were treated with DNA methylation inhibitors, including 5 -azacytidine, procainamide and hydralazine, then injected into syngeneic mice. The recipients developed a lupus-like disease with anti-DNA antibodies, as well as a liver disease resembling primary biliary cirrhosis [180]. More recent work has shown that the same region flanking the CD11a promoter is demethylated in the drug treated $T$ cells as in $T$ cells from patients with active lupus [B.C. Richardson et al., unpublished results]. The DNA hypomethylation in lupus $\mathrm{T}$ cells appears to result from decreased extracellular signal-related kinase (ERK) pathway signaling, leading to decreased Dnmt1 and Dnmt3a expression [B.C. Richardson et al., unpublished results].

Methylation and cancer. Both global hypomethylation and regional hypermethylation have been recognized as characteristic of many tumors [181]. Hypomethylation has been suggested to lead to activation of protooncogenes such as H-RAS and C-MYC, as well as members of the MAGE gene family (reviewed in [182]). However, the last few years has seen a remarkable explosion in research concerning the association of $\mathrm{CpG}$ island hypermethylation with tumorigenesis. This interest has arisen from the observation that $\mathrm{CpG}$ islands within the promot- 
ers of many genes are found to be hypermethylated and suppressed in a variety of tumors [183,184].

Although the association between $\mathrm{CpG}$ island hypermethylation and cancer has not been clearly shown to be causal, examination of affected genes is highly suggestive of a such a relationship. Causality predicts that hypermethylation of $\mathrm{CpG}$ islands within the $5^{\prime}$ region of genes with various growth suppressing functions leads to suppressed gene expression with resultant dysregulated cell growth. Genes with hypermethylated $\mathrm{CpG}$ islands so far include tumor suppressor genes such as the RB1 gene in retinoblastomas and other tumors $[185,186]$ and the von Hippel Lindau (VHL) gene in renal carcinoma [187]; genes involved in apoptosis such as the death-associated protein (DAP) in lung cancer [188]; and DNA-repair genes such as MLH1 in colorectal tumors [189, 190]. Methylation changes for a specific gene occur quite frequently for a given cancer type [184]. Both CpG island hypermethylation and mutation changes in a specific gene can be found in a particular tumor type, further supporting the argument for a causal role of DNA methylation in tumorigenesis [191]. As discussed below, methylation changes may occur in normal tissue and precede the development of cancer $[192,193]$.

Interestingly and very relevant for diagnostics, abnormal promoter methylation occurs in the same location within an affected gene for different individuals and regardless of the tumor type [194]. The fact that the phenomenon of $\mathrm{CpG}$ island hypermethylation is relatively common in a wide variety of tumors suggests that for some reason, a directed methylation event targeted to $\mathrm{CpG}$ islands is occurring, whose normal biological equivalent is unclear at this time.

Methylation and ageing. Age-related changes in the levels of DNA methylation within promoter regions have the potential to mediate abnormal gene expression. Such changes might contribute to tissue senescence as well as the increased incidence of malignancy that occurs with age [195]. Early studies demonstrated that global levels of DNA methylation tend to decrease with age [196-199], although there are exceptions [200]. Such changes may represent demethylation primarily of repetitive DNA sequences [197, 201, 202]. Age-related demethylation of endogenous retroviruses has also been demonstrated and may be associated with the increase in expression of these sequences that occurs with age [203]. Our group examined total methylcytosine content of human $\mathrm{T}$ cells and found that although an increase accompanies the differentiation of thymocytes into mature $\mathrm{T}$ cells, total methylcytosine content decreases with age [204].

Individual genes undergo tissue-specific methylation changes with age, such that demethylation may occur in one tissue and not another [205]. For example, the c-Myc gene demethylated with age in murine spleen while dis- playing increased methylation at some CG dinucleotides in murine liver [206], although the methylation changes did not consistently correlate with transcript levels [207]. Other genes have also been found to display age-related changes in methylation [205]; however, promoter involvement and changes in gene expression have not been clearly defined.

Because of their potential to influence the level of gene expression, $\mathrm{CpG}$ islands within the promoters of genes which are normally hypomethylated have recently been analyzed for evidence of age-associated increases in methylation (reviewed in [208, 209]). This work arose from the observation that gene inactivation in many tumors occurs as a result of hypermethylation of CG islands within their promoters, especially those of tumor suppressor genes (reviewed in [210]). The estrogen receptor (ER) gene was first identified as being associated with age-related $\mathrm{CpG}$ island hypemethylation in a subpopulation of normal human colonic mucosa cells [192]. Further studies by the same group demonstrated diminished or absent ER expression in virtually all colorectal tumors examined, and introduction of an exogenous unmethylated ER gene caused marked growth suppression, suggesting that ER CpG island hypermethylation may be an earlier event in the development of colorectal tumors [192]. Further analysis of $\mathrm{CpG}$ island methylation in colonic tissue revealed that $19 / 30(63 \%)$ of $\mathrm{CpG}$ islands examined had undergone progressive methylation in an age-dependent fashion [193]. Aside from the increased risk of tumor development that is associated with ageing, it remains to be seen whether hypermethylation of $\mathrm{CpG}$ islands is a factor in other aspects of age-related gene dysfunction.

Our group has studied the effects of a heterozygous deletion mutation of Dnmt1 (Dnmt1+/-) with respect to immune senescence and autoimmunity [211]. As we had already shown that inhibiting T cell DNA methylation leads to autoimmunity, we hypothesized that Dnmt1+/- mice would develop immune senescence and autoimmune disease more rapidly than their normal littermates. Surprisingly, Dnmt1+/- mice showed a reduced degree of agerelated lymphocytic infiltration in the liver and salivary glands, as well as lower titers of anti-DNA antibodies, compared with their normal littermates. Analysis of $\mathrm{T}$ cells from Dnmt1+/- mice revealed that the CD44 highmemory subset developed more slowly, IL-2 secretion was maintained in old age and $\mathrm{T}$ cell proliferative responses increased rather than decreased with age. Analysis of lymphocyte DNA total methylcytosine content demonstrated that although DNA from young Dnmt1+/mice was hypomethylated, the methylcytosine content paradoxically increased with age compared with normal littermates, whose lymphocyte methylcytosine content declined with age. Interestingly, when transcript levels for methylcytosine-binding proteins were analyzed in 
brain tissue, we found that although $\mathrm{MeCP} 2$ showed an age-related decline in normal littermates, levels in Dnmt $1+/$ - mice remained unchanged.

\section{Conclusion}

Over the past few years there has been enormous progress in our understanding of the mechanisms of DNA methylation and the role that this process plays in normal cellular function as well as in certain congenital diseases, tumor development, aging and autoimmune disease. It is likely that the next few years will lead to further insights into this process, with the expectation that such knowledge will allow the development of therapeutic modalities able to manipulate methylcytosine levels in DNA or interfere with the normal downstream effects of differentially methylated DNA. Certainly, the newly identified DNA methyltransferases and methylcytosine-binding proteins will be targets for pharmocological or genetic inhibition, especially in the development of anticancer agents. However, further research will be required to understand how abnormalities of the methylation machinery lead to disease states and what components of this machinery will be appropriate targets for therapeutic intervention.

1 Hotchkiss R. D. (1948) The quantitative separation of purines, pyrimidines, and nucleosides by paper chromatography. J. Biol. Chem. 175: 315-332

2 Razin A. and Riggs A. D. (1980) DNA methylation and gene function. Science 210: $604-610$

3 Ehrlich M. and Wang R. Y. (1981) 5-Methylcytosine in eukaryotic DNA. Science 212: 1350-1357

4 Razin A. and Cedar H. (1977) Distribution of 5-methylcytosine in chromatin. Proc. Natl. Acad. Sci. USA 74: 2725-2728

5 McClelland M. and Ivarie R. (1982) Asymmetrical distribution of $\mathrm{CpG}$ in an 'average' mammalian gene. Nucleic Acids Res. 10: 7865-7877

6 Antequera F. and Bird A. P. (1988) Unmethylated CpG islands associated with genes in higher plant DNA. EMBO J. 7: $2295-2299$

7 Tykocinski M. L. and Max E. E. (1984) CG dinucleotide clusters in MHC genes and in $5^{\prime}$ demethylated genes. Nucleic Acids Res. 12: 4385-4396

8 Cooper D. N., Taggart M. H. and Bird A. P. (1983) Unmethylated domains in vertebrate DNA. Nucleic Acids Res. 11: $647-658$

9 Antequera F. and Bird A. (1993) CpG islands. In: DNA Methylation: Molecular Biology and Biological Significance, pp. 169-185, Jost J. P. and Saluz H. P. (eds), Birkhäuser, Basel

10 Lindahl T. (1982) DNA repair enzymes. Ann. Rev. Biochem. 51: $61-87$

11 Lindsay S. and Bird A. P. (1987) Use of restriction enzymes to detect potential gene sequences in mammalian DNA. Nature 327: $336-338$

12 Tazi J. and Bird A. (1990) Alternative chromatin structure at CpG islands. Cell 60: 909-920

13 Larsen F., Gundersen G. and Prydz H. (1992) Choice of enzymes for mapping based on $\mathrm{CpG}$ islands in the human genome. Genet. Anal. Tech. Appl. 9: 80-85
14 Jones P. A. (1999) The DNA methylation paradox. Trends Genet. 15: 34-37

15 Yoder J. A., Walsh C. P. and Bestor T. H. (1997) Cytosine methylation and the ecology of intragenomic parasites. Trends Genet. 13: $335-340$

16 Bestor T. H. (1998) The host defence function of genomic methylation patterns. In: Novartis Foundation Symposium, vol. 214, Epigenetics, pp. 187-199, Chadwick D. J. and Wollfe A. P. (eds), Wiley, Chichester

17 Matzke M. A., Mette M. F., Aufsatz W., Jakowitsch J. and Matzke A. J. (1999) Host defenses to parasitic sequences and the evolution of epigenetic control mechanisms. Genetica 107: $271-287$

18 Bestor T., Laudano A., Mattaliano R. and Ingram V. (1988) Cloning and sequencing of a cDNA encoding DNA methyltransferase of mouse cells. The carboxyl-terminal domain of the mammalian enzymes is related to bacterial restriction methyltransferases. J. Mol. Biol. 203: 971-983

19 Leonhardt H., Page A. W., Weier H. U. and Bestor T. H. (1992) A targeting sequence directs DNA methyltransferase to sites of DNA replication in mammalian nuclei. Cell 71: 865-873

20 Fatemi M., Hermann A., Pradhan S. and Jeltsch A. (2001) The activity of the murine DNA methyltransferase Dnmt1 is controlled by interaction of the catalytic domain with the N-terminal part of the enzyme leading to an allosteric activation of the enzyme after binding to methylated DNA. J. Mol. Biol. 309: $1189-1199$

21 Araujo F. D., Croteau S., Slack A. D., Milutinovic S., Bigey P., Price G. B. et al. (2001) The Dnmt1 target recognition domain resides in the $\mathrm{n}$ terminus. J. Biol. Chem. 276: 6930-6936

22 Klimasauskas S., Kumar S., Roberts R. J. and Cheng X. (1994) HhaI methyltransferase flips its target base out of the DNA helix. Cell 76: 357-369

23 Posfai J., Bhagwat A. S., Posfai G. and Roberts R. J. (1989) Predictive motifs derived from cytosine methyltransferases. Nucleic Acids Res. 17: 2421-2435

24 Yoder J. A., Soman N. S., Verdine G. L. and Bestor T. H. (1997) DNA (cytosine-5)-methyltransferases in mouse cells and tissues. Studies with a mechanism-based probe. J. Mol. Biol. 270: 385-395

25 Takagi H., Tajima S. and Asano A. (1995) Overexpression of DNA methyltransferase in myoblast cells accelerates myotube formation. Eur. J. Biochem. 231: 282-291

26 Vertino P. M., Yen R. W., Gao J. and Baylin S. B. (1996) De novo methylation of $\mathrm{CpG}$ island sequences in human fibroblasts overexpressing DNA (cytosine-5-)-methyltransferase. Mol. Cell. Biol. 16: 4555-4565

27 Mikovits J. A., Young H. A., Vertino P., Issa J. P., Pitha P. M., Turcoski-Corrales S. et al. (1998) Infection with human immunodeficiency virus type 1 upregulates DNA methyltransferase, resulting in de novo methylation of the gamma interferon (IFN-gamma) promoter and subsequent downregulation of IFN-gamma production. Mol. Cell. Biol. 18: 5166-5177

28 Mertineit C., Yoder J. A., Taketo T., Laird D. W., Trasler J. M. and Bestor T. H. (1998) Sex-specific exons control DNA methyltransferase in mammalian germ cells. Development 125: $889-897$

29 Howell C. Y., Bestor T. H., Ding F., Latham K. E., Mertineit C., Trasler J. M. et al. (2001) Genomic imprinting disrupted by a maternal effect mutation in the Dnmtl gene. Cell 104: $829-838$

30 Aguirre-Arteta A. M., Grunewald I., Cardoso M. C. and Leonhardt H. (2000) Expression of an alternative Dnmt1 isoform during muscle differentiation. Cell Growth Differ. 11: 551-559

31 Li E., Bestor T. H. and Jaenisch R. (1992) Targeted mutation of the DNA methyltransferase gene results in embryonic lethality. Cell 69: 915-926

32 Li E., Beard C. and Jaenisch R. (1993) Role for DNA methylation in genomic imprinting. Nature 366: $362-365$ 
33 Sado T., Fenner M. H., Tan S. S., Tam P., Shioda T. and Li E. (2000) $\mathrm{X}$ inactivation in the mouse embryo deficient for Dnmt1: distinct effect of hypomethylation on imprinted and random X inactivation. Dev. Biol. 225: 294-303

34 Jackson-Grusby L., Beard C., Possemato R., Tudor M., Fambrough D., Csankovszki G. et al. (2001) Loss of genomic methylation causes p53-dependent apoptosis and epigenetic deregulation. Nat. Genet. 27: 31-39

35 Fitzpatrick D. R., Lee P. P., Beard C., Jessup H. K., Lehar S., Nguyen S. et al. (2000) Loss of DNA methylation has profound effects on $\mathrm{T}$ lymphocyte proliferation, survival and function. FASEB J. 14: A1223

36 Fan G., Beard C., Chen R. Z., Csankovszki G., Sun Y., Siniaia M. et al. (2001) DNA hypomethylation perturbs the function and survival of CNS neurons in postnatal animals. J. Neurosci. 21: 788-797

37 Chuang L. S., Ian H. I., Koh T. W., Ng H. H., Xu G. and Li B. F. (1997) Human DNA-(cytosine-5) methyltransferase-PCNA complex as a target for p21WAF1. Science 277: 1996-2000

38 Robertson K. D., Ait-Si-Ali S., Yokochi T., Wade P. A., Jones P. L. and Wolffe A. P. (2000) DNMT1 forms a complex with $\mathrm{Rb}, \mathrm{E} 2 \mathrm{~F} 1$ and HDAC1 and represses transcription from E2Fresponsive promoters. Nat. Genet. 25: $338-342$

39 Rountree M. R., Bachman K. E. and Baylin S. B. (2000) DNMT1 binds HDAC2 and a new co-repressor, DMAP1, to form a complex at replication foci. Nat. Genet. 25: 269-277

40 Lei H., Oh S. P., Okano M., Juttermann R., Goss K. A., Jaenisch R. et al. (1996) De novo DNA cytosine methyltransferase activities in mouse embryonic stem cells. Development 122: 3195-3205

41 Yoder J. A. and Bestor T. H. (1998) A candidate mammalian DNA methyltransferase related to pmtlp of fission yeast. Hum. Mol. Genet. 7: 279-284

42 Okano M., Xie S. and Li E. (1998) Dnmt2 is not required for de novo and maintenance methylation of viral DNA in embryonic stem cells. Nucleic Acids Res. 26: 2536-2540

43 Okano M., Xie S. and Li E. (1998) Cloning and characterization of a family of novel mammalian DNA (cytosine-5) methyltransferases. Nat. Genet. 19: 219-220

44 Xie S., Wang Z., Okano M., Nogami M., Li Y., He W. W. et al. (1999) Cloning, expression and chromosome locations of the human DNMT3 gene family. Gene 236: 87-95

45 Fuks F., Burgers W. A., Godin N., Kasai M. and Kouzarides T. (2001) Dnmt3a binds deacetylases and is recruited by a sequence-specific repressor to silence transcription. EMBO J. 20: $2536-2544$

46 Okano M., Bell D. W., Haber D. A. and Li E. (1999) DNA methyltransferases Dnmt3a and Dnmt3b are essential for de novo methylation and mammalian development. Cell 99: $247-257$

47 Pestano G. A., Zhou Y., Trimble L. A., Daley J., Weber G. F. and Cantor H. (1999) Inactivation of misselected CD8 T cells by CD8 gene methylation and cell death. Science 284: 1187-1191

48 Robertson K. D., Uzvolgyi E., Liang G., Talmadge C., Sumegi J., Gonzales F. A. et al. (1999) The human DNA methyltransferases (DNMTs) 1, 3a and 3b: coordinate mRNA expression in normal tissues and overexpression in tumors. Nucleic Acids Res. 27: 2291-2298

49 Monk M., Boubelik M. and Lehnert S. (1987) Temporal and regional changes in DNA methylation in the embryonic, extraembryonic and germ cell lineages during mouse embryo development. Development 99: 371-382

50 Kafri T., Ariel M., Brandeis M., Shemer R., Urven L., McCarrey J. et al. (1992) Developmental pattern of gene-specific DNA methylation in the mouse embryo and germ line. Genes Dev. 6: $705-714$

51 Paroush Z., Keshet I., Yisraeli J. and Cedar H. (1990) Dynamics of demethylation and activation of the alpha-actin gene in myoblasts. Cell 63: 1229-1237
52 Wolffe A. P., Jones P. L. and Wade P. A. (1999) DNA demethylation. Proc. Natl. Acad. Sci. USA 96: 5894-5896

53 Jost J. P. (1993) Nuclear extracts of chicken embryos promote an active demethylation of DNA by excision repair of 5methyldeoxycytidine. Proc. Natl. Acad. Sci. USA 90: $4684-4688$

54 Jost J. P., Siegmann M., Sun L. and Leung R. (1995) Mechanisms of DNA demethylation in chicken embryos. Purification and properties of a 5-methylcytosine-DNA glycosylase. J. Biol. Chem. 270: 9734-9739

55 Fremont M., Siegmann M., Gaulis S., Matthies R., Hess D. and Jost J. P. (1997) Demethylation of DNA by purified chick embryo 5-methylcytosine-DNA glycosylase requires both protein and RNA. Nucleic Acids Res. 25: 2375-2380

56 Jost J. P., Schwarz S., Hess D., Angliker H., Fuller-Pace F. V., Stahl H. et al. (1999) A chicken embryo protein related to the mammalian DEAD box protein p68 is tightly associated with the highly purified protein-RNA complex of 5- MeC-DNA glycosylase. Nucleic Acids Res. 27: 3245-3252

57 Zhu B., Benjamin D., Zheng Y., Angliker H., Thiry S., Siegmann M. et al. (2001) Overexpression of 5-methylcytosine DNA glycosylase in human embryonic kidney cells EcR293 demethylates the promoter of a hormone-regulated reporter gene. Proc. Natl. Acad. Sci. USA 98: 5031-5036

58 Hendrich B., Hardeland U., Ng H. H., Jiricny J. and Bird A. (1999) The thymine glycosylase MBD4 can bind to the product of deamination at methylated $\mathrm{CpG}$ sites. Nature 401: 301-304

59 Bhattacharya S. K., Ramchandani S., Cervoni N. and Szyf M. (1999) A mammalian protein with specific demethylase activity for mCpG DNA. Nature 397: 579-583

$60 \mathrm{Ng} \mathrm{H}$. H., Zhang Y., Hendrich B., Johnson C. A., Turner B. M., Erdjument-Bromage H. et al. (1999) MBD2 is a transcriptional repressor belonging to the MeCP1 histone deacetylase complex. Nat. Genet. 23: 58-61

61 Wade P. A., Gegonne A., Jones P. L., Ballestar E., Aubry F. and Wolffe A. P. (1999) Mi-2 complex couples DNA methylation to chromatin remodelling and histone deacetylation. Nat. Genet. 23: $62-66$.

62 Holliday R. and Pugh J. E. (1975) DNA modification mechanisms and gene activity during development. Science 187: $226-232$

63 Riggs A. D. (1975) X inactivation, differentiation, and DNA methylation. Cytogenet. Cell Genet. 14: 9-25

64 Waalwijk C. and Flavell R. A. (1978) DNA methylation at a CCGG sequence in the large intron of the rabbit beta-globin gene: tissue-specific variations. Nucleic Acids Res. 5: $4631-4634$

65 McGhee J. D. and Ginder G. D. (1979) Specific DNA methylation sites in the vicinity of the chicken beta-globin genes. Nature 280: 419-420

66 Mandel J. L. and Chambon P. (1979) DNA methylation: organ specific variations in the methylation pattern within and around ovalbumin and other chicken genes. Nucleic Acids Res. 7: 2081-2103

67 van der Ploeg L. H. and Flavell R. A. (1980) DNA methylation in the human gamma delta beta-globin locus in erythroid and nonerythroid tissues. Cell 19: 947-958

68 Taylor S. M. and Jones P. A. (1979) Multiple new phenotypes induced in 10T1/2 and $3 \mathrm{~T} 3$ cells treated with 5-azacytidine. Cell 17: 771-779

69 Jones P. A. and Taylor S. M. (1980) Cellular differentiation, cytidine analogs and DNA methylation. Cell 20: 85-93

70 Santi D. V., Norment A. and Garrett C. E. (1984) Covalent bond formation between a DNA-cytosine methyltransferase and DNA containing 5-azacytosine. Proc. Natl. Acad. Sci. USA 81: 6993-6997

71 Juttermann R., Li E. and Jaenisch R. (1994) Toxicity of 5-aza$2^{\prime}$-deoxycytidine to mammalian cells is mediated primarily by 
covalent trapping of DNA methyltransferase rather than DNA demethylation. Proc. Natl. Acad. Sci. USA 91: 11797-11801

72 Jones P. A. (1985) Effects of 5-azacytidine and its 2'-deoxyderivative on cell differentiation and DNA methylation. Pharmacol. Ther. 28: $17-27$

73 Sasaki R. and Miura Y. (1986) Effect of 5-azacytidine on the differentiation of human leukemia K-562 cells. Int. J. Cell Cloning 4: 192-202

74 Alvarez E., Elliott B. E., Houghton A. N. and Kerbel R. S. (1988) Heritable high frequency modulation of antigen expression in neoplastic cells exposed to 5-aza-2'-deoxycytidine or hydroxyurea: analysis and implications. Cancer Res. 48: $2440-2445$

75 Mohandas T., Sparkes R. S. and Shapiro L. J. (1981) Reactivation of an inactive human $\mathrm{X}$ chromosome: evidence for $\mathrm{X}$ inactivation by DNA methylation. Science 211: 393-396

76 Bartolomei M. S. and Tilghman S. M. (1997) Genomic imprinting in mammals. Ann. Rev. Genet. 31: 493-525

77 Brannan C. I. and Bartolomei M. S. (1999) Mechanisms of genomic imprinting. Curr. Opin. Genet. Dev. 9: 164-170

78 Feil R. and Khosla S. (1999) Genomic imprinting in mammals: an interplay between chromatin and DNA methylation? Trends Genet. 15: 431-435

79 Pfeifer K. (2000) Mechanisms of genomic imprinting. Am. J. Hum. Genet. 67: 777-787

80 Reik W. and Walter J. (2001) Genomic imprinting: parental influence on the genome. Nat. Rev. Genet. 2: 21-32

81 Paulsen M., El-Maarri O., Engemann S., Strodicke M., Franck O., Davies K. et al. (2000) Sequence conservation and variability of imprinting in the Beckwith-Wiedemann syndrome gene cluster in human and mouse. Hum. Mol. Genet. 9: 1829-1841

82 El Kharroubi A., Piras G. and Stewart C. L. (2001) DNA demethylation reactivates a subset of imprinted genes in uniparental mouse embryonic fibroblasts. J. Biol. Chem. 276: $8674-8680$

83 Wolffe A. P. (2000) Transcriptional control: imprinting insulation. Curr Biol 10: R463-465.

84 Allshire R. and Bickmore W. (2000) Pausing for thought on the boundaries of imprinting. Cell 102: 705-708

85 Ben-Porath I. and Cedar H. (2000) Imprinting: focusing on the center. Curr. Opin. Genet. Dev. 10: 550-554

86 Bell A. C., West A. G. and Felsenfeld G. (2001) Insulators and boundaries: versatile regulatory elements in the eukaryotic genome. Science 291: 447-450

87 Haig D. and Westoby M. (1989) Parent-specific gene expression and the triploid endosperm. Am. Naturalist 134: $147-155$

88 Moore T. and Haig D. (1991) Genomic imprinting in mammalian development: a parental tug-of-war. Trends Genet. 7: $45-49$

89 Hurst L. D. and McVean G. T. (1998) Do we understand the evolution of genomic imprinting? Curr. Opin. Genet. Dev. 8: 701-708

90 Preece M. A. and Moore G. E. (2000) Genomic imprinting, uniparental disomy and foetal growth. Trends Endocrinol. Metab. 11: 270-275

91 Heard E., Clerc P. and Avner P. (1997) X-chromosome inactivation in mammals. Ann. Rev. Genet. 31: 571-610

92 Lee J. T. and Jaenisch R. (1997) The (epi)genetic control of mammalian X-chromosome inactivation. Curr. Opin. Genet. Dev. 7: $274-280$

93 Pereira L. V. and Vasques L. R. (2000) X-chromosome inactivation: lessons from transgenic mice. Gene 255: 363-371

94 Avner P. and Heard E. (2001) X-chromosome inactivation: counting, choice and initiation. Nat. Rev. Genet. 2: 59-67

95 Stein R., Razin A. and Cedar H. (1982) In vitro methylation of the hamster adenine phosphoribosyltransferase gene inhibits its expression in mouse L cells. Proc. Natl. Acad. Sci. USA 79: $3418-3422$
96 Busslinger M., Hurst J. and Flavell R. A. (1983) DNA methylation and the regulation of globin gene expression. Cell 34: 197-206

97 Siegfried Z., Eden S., Mendelsohn M., Feng X., Tsuberi B. Z. and Cedar H. (1999) DNA methylation represses transcription in vivo. Nat. Genet. 22: 203-206

98 Comb M. and Goodman H. M. (1990) CpG methylation inhibits proenkephalin gene expression and binding of the transcription factor AP-2. Nucleic Acids Res. 18: 3975-3982

99 Iguchi-Ariga S. M. and Schaffner W. (1989) CpG methylation of the cAMP-responsive enhancer/promoter sequence TGACGTCA abolishes specific factor binding as well as transcriptional activation. Genes Dev. 3: 612-619

100 Prendergast G. C. and Ziff E. B. (1991) Methylation-sensitive sequence-specific DNA binding by the c-Myc basic region. Science 251: $186-189$

101 Clark S. J., Harrison J. and Molloy P. L. (1997) Sp1 binding is inhibited by $(\mathrm{m}) \mathrm{Cp}(\mathrm{m}) \mathrm{CpG}$ methylation. Gene 195: 67-71

102 Harrington M. A., Jones P. A., Imagawa M. and Karin M. (1988) Cytosine methylation does not affect binding of transcription factor Sp1. Proc. Natl. Acad. Sci. USA 85: $2066-$ 2070

$103 \mathrm{Yu}$ F., Thiesen J. and Stratling W. H. (2000) Histone deacetylase-independent transcriptional repression by methyl-CpGbinding protein 2. Nucleic Acids Res. 28: 2201-2206

104 Lewis J. D., Meehan R. R., Henzel W. J., Maurer-Fogy I., Jeppesen P., Klein F. et al. (1992) Purification, sequence and cellular localization of a novel chromosomal protein that binds to methylated DNA. Cell 69: 905-914

105 Nan X., Meehan R. R. and Bird A. (1993) Dissection of the methyl-CpG binding domain from the chromosomal protein MeCP2. Nucleic Acids Res. 21: 4886-4892

106 Nan X., Campoy F. J. and Bird A. (1997) MeCP2 is a transcriptional repressor with abundant binding sites in genomic chromatin. Cell 88: 471-481

107 Nan X., Tate P., Li E. and Bird A. (1996) DNA methylation specifies chromosomal localization of MeCP2. Mol. Cell. Biol. 16: 414-421

108 Nan X., Ng H. H., Johnson C. A., Laherty C. D., Turner B. M., Eisenman R. N. et al. (1998) Transcriptional repression by the methyl-CpG-binding protein $\mathrm{MeCP} 2$ involves a histone deacetylase complex. Nature 393: 386-389

$109 \mathrm{Ng} \mathrm{H}$. H. and Bird A. (2000) Histone deacetylases: silencers for hire. Trends Biochem. Sci. 25: 121-126

110 Jones P. L., Veenstra G. J., Wade P. A., Vermaak D., Kass S. U., Landsberger N. et al. (1998) Methylated DNA and MeCP2 recruit histone deacetylase to repress transcription. Nat. Genet. 19: $187-191$

111 Meehan R. R., Lewis J. D., McKay S., Kleiner E. L. and Bird A. P. (1989) Identification of a mammalian protein that binds specifically to DNA containing methylated CpGs. Cell 58: 499-507

112 Zhang Y., Ng H. H., Erdjument-Bromage H., Tempst P., Bird A. and Reinberg D. (1999) Analysis of the NuRD subunits reveals a histone deacetylase core complex and a connection with DNA methylation. Genes Dev. 13: 1924-1935

113 Boeke J., Ammerpohl O., Kegel S., Moehren U. and Renkawitz R. (2000) The minimal repression domain of MBD2b overlaps with the methyl-CpG-binding domain and binds directly to Sin3A. J. Biol. Chem. 275: $34963-$ 34967

114 Tatematsu K. I., Yamazaki T. and Ishikawa F. (2000) MBD2MBD3 complex binds to hemi-methylated DNA and forms a complex containing DNMT1 at the replication foci in late $\mathrm{S}$ phase. Genes Cells 5: 677-688

115 Hendrich B., Guy J., Ramsahoye B., Wilson V. A. and Bird A. (2001) Closely related proteins MBD2 and MBD3 play distinctive but interacting roles in mouse development. Genes Dev. 15: 710-723 
116 Hendrich B. and Bird A. (1998) Identification and characterization of a family of mammalian methyl-CpG binding proteins. Mol. Cell. Biol. 18: 6538-6547

117 Hendrich B., Abbott C., McQueen H., Chambers D., Cross S. and Bird A. (1999) Genomic structure and chromosomal mapping of the murine and human Mbd1, Mbd2, Mbd3, and Mbd4 genes. Mamm. Genome 10: 906-912

$118 \mathrm{Ng} \mathrm{H}$. H., Jeppesen P. and Bird A. (2000) Active repression of methylated genes by the chromosomal protein MBD1. Mol. Cell. Biol. 20: 1394-1406

119 Zhu B., Zheng Y., Angliker H., Schwarz S., Thiry S., Siegmann M. et al. (2000) 5-Methylcytosine DNA glycosylase activity is also present in the human MBD4 (G/T mismatch glycosylase) and in a related avian sequence. Nucleic Acids Res. 28: $4157-4165$

120 Young H. A. (1996) Regulation of interferon-gamma gene expression. J. Interferon Cytokine Res. 16: 563-568

121 Fukunaga R., Matsuyama M., Okamura H., Nagata K., Nagata S. and Sokawa Y. (1986) Undermethylation of interferongamma gene in human $\mathrm{T}$ cell lines and normal $\mathrm{T}$ lymphocytes. Nucleic Acids Res. 14: 4421-4436

122 Young H. A., Ghosh P., Ye J., Lederer J., Lichtman A., Gerard J. R. et al. (1994) Differentiation of the T helper phenotypes by analysis of the methylation state of the IFN-gamma gene. J. Immunol. 153: 3603-3610

123 Melvin A. J., McGurn M. E., Bort S. J., Gibson C. and Lewis D. B. (1995) Hypomethylation of the interferon-gamma gene correlates with its expression by primary T-lineage cells. Eur. J. Immunol. 25: 426-430

124 Penix L. A., Sweetser M. T., Weaver W. M., Hoeffler J. P., Kerppola T. K. and Wilson C. B. (1996) The proximal regulatory element of the interferon-gamma promoter mediates selective expression in T cells. J. Biol. Chem. 271: 31964-31972

125 Katamura K., Fukui T., Kiyomasu T., Iio J., Tai G., Ueno H. et al. (1998) IL-4 and prostaglandin E2 inhibit hypomethylation of the $5^{\prime}$ regulatory region of IFN-gamma gene during differentiation of naive CD4+ T cells. Mol. Immunol. 35: 39-45

126 Cheng X. and Lopez D. M. (1998) CD4+, but not CD8+, T cells from mammary tumor-bearing mice have a down- regulated production of IFN-gamma: role of phosphatidyl serine. J. Immunol. 160: 2735-2741

127 Agarwal S. and Rao A. (1998) Modulation of chromatin structure regulates cytokine gene expression during $\mathrm{T}$ cell differentiation. Immunity 9: 765-775

128 Bird J. J., Brown D. R., Mullen A. C., Moskowitz N. H., Mahowald M. A., Sider J. R. et al. (1998) Helper T cell differentiation is controlled by the cell cycle. Immunity 9: 229-237

129 Takemoto N., Kamogawa Y., Jun Lee H., Kurata H., Arai K. I., O'Garra A. et al. (2000) Cutting edge: chromatin remodeling at the IL-4/IL-13 intergenic regulatory region for Th2-specific cytokine gene cluster. J. Immunol. 165: 6687-6691

130 Fitzpatrick D. R., Shirley K. M., McDonald L. E., BielefeldtOhmann H., Kay G. F. and Kelso A. (1998) Distinct methylation of the interferon gamma (IFN-gamma) and interleukin 3 (IL-3) genes in newly activated primary CD8+ T lymphocytes: regional IFN-gamma promoter demethylation and mRNA expression are heritable in CD44(high)CD8+ T cells. J. Exp. Med. 188: 103-117

131 Richardson B., Kahn L., Lovett E. J. and Hudson J. (1986) Effect of an inhibitor of DNA methylation on T cells. I. 5-Azacytidine induces T4 expression on T8+ T cells. J. Immunol 137: $35-39$

132 Carbone A. M., Marrack P. and Kappler J. W. (1988) Demethylated CD8 gene in CD4+ T cells suggests that CD4+ cells develop from CD8+ precursors. Science 242: 11741176

133 Tutt Landolfi M. M., Scollay R. and Parnes J. R. (1997) Specific demethylation of the CD4 gene during CD4 T lymphocyte differentiation. Mol. Immunol. 34: 53-61
134 Hyman R. and Stallings V. (1992) Coordinate change in phenotype in a mouse cell line selected for CD8 expression. Immunogenetics 36: 149-156

135 Hamerman J. A., Page S. T. and Pullen A. M. (1997) Distinct methylation states of the CD8 beta gene in peripheral T cells and intraepithelial lymphocytes. J. Immunol. 159: 1240-1246

136 Carbone A. M., Marrack P. and Kappler J. W. (1988) Remethylation at sites $5^{\prime}$ of the murine Lyt-2 gene in association with shutdown of Lyt-2 expression. J. Immunol. 141: 1369-1375

137 Morris A. C., Spangler W. E. and Boss J. M. (2000) Methylation of class II trans-activator promoter IV: a novel mechanism of MHC class II gene control. J. Immunol. 164: 4143-4149

138 van den Elsen P. J., van der Stoep N., Vietor H. E., Wilson L., van Zutphen M. and Gobin S. J. (2000) Lack of CIITA expression is central to the absence of antigen presentation functions of trophoblast cells and is caused by methylation of the IFN-gamma inducible promoter (PIV) of CIITA. Hum. Immunol. 61: 850-862

139 Barbieri R., Nastruzzi C., Volinia S., Villa M., Piva R., Giacomini P. et al. (1990) Methylation pattern of the HLA-DR alpha gene in human tissues. J. Immunogenet. 17: 51-66

140 Carrington M. N., Chedid M., Ting J. P. and Ward F. E. (1987) Differential expression of the HLA-DR genes in various melanoma cell lines treated with interferon-gamma: methylation of the HLA-DR alpha gene in these lines is not correlated with its expression. Hum. Immunol. 18: 151-161

141 Wang Y. and Peterlin B. M. (1986) Methylation patterns of HLA-DR alpha genes in six mononuclear cell lines. Immunogenetics 24: 298-303

142 Lee J. S. and O'Neill L. (1987) Methylation of the HLA-DR alpha gene is positively correlated with expression. Immunogenetics 26: $92-98$

143 Gambari R., Del Senno L., Barbieri R., Buzzoni D., Gustafsson K., Giacomini P. et al. (1986) Lack of correlation between hypomethylation and expression of the HLA-DR alpha gene. Eur. J. Immunol. 16: 365-369

144 Pontarotti P., Chimini G., Nguyen C., Boretto J. and Jordan B. R. (1988) CpG islands and HTF islands in the HLA class I region: investigation of the methylation status of class I genes leads to precise physical mapping of the HLA-B and -C genes. Nucleic Acids Res. 16: 6767-6778

145 Tanaka K., Appella E. and Jay G. (1983) Developmental activation of the $\mathrm{H}-2 \mathrm{~K}$ gene is correlated with an increase in DNA methylation. Cell 35: 457-465

146 Tanaka K., Barra Y., Isselbacher K. J., Khoury G. and Jay G. (1986) Developmental and tissue-specific regulation of the Q10 class I gene by DNA methylation. Proc. Natl. Acad. Sci. USA 83: $7598-7602$

147 Guillaudeux T., Rodriguez A. M., Girr M., Mallet V., Ellis S. A., Sargent I. L. et al. (1995) Methylation status and transcriptional expression of the MHC class I loci in human trophoblast cells from term placenta. J. Immunol. 154: 3283-3299

148 Krangel M. S. (2001) V(D)J recombination becomes accessible. J. Exp. Med. 193: F27-30

149 Yagi M. and Koshland M. E. (1981) Expression of the J chain gene during $\mathrm{B}$ cell differentiation is inversely correlated with DNA methylation. Proc. Natl. Acad. Sci. USA 78: 4907-4911

150 Storb U. and Arp B. (1983) Methylation patterns of immunoglobulin genes in lymphoid cells: correlation of expression and differentiation with undermethylation. Proc. Natl. Acad. Sci. USA 80: $6642-6646$

151 Sakamoto S., Ortaldo J. R. and Young H. A. (1988) Methylation patterns of the $\mathrm{T}$ cell receptor beta-chain gene in $\mathrm{T}$ cells, large granular lymphocytes, B cells and monocytes. J. Immunol. 140: $654-660$

152 Sakamoto S., Mathieson B. J., Komschlies K. L., Bhat N. K. and Young H. A. (1989) The methylation state of the T cell 
antigen receptor beta chain gene in subpopulations of mouse thymocytes. Eur. J. Immunol. 19: 873-879

153 Chattopadhyay S., Whitehurst C. E., Schwenk F. and Chen J. (1998) Biochemical and functional analyses of chromatin changes at the TCR- beta gene locus during CD4-CD8- to CD4+CD8+ thymocyte differentiation. J. Immunol. 160: $1256-1267$

154 Santoso B., Ortiz B. D. and Winoto A. (2000) Control of organ-specific demethylation by an element of the T-cell receptor-alpha locus control region. J. Biol. Chem. 275: $1952-1958$

155 Mathieu N., Hempel W. M., Spicuglia S., Verthuy C. and Ferrier P. (2000) Chromatin remodeling by the T cell receptor (TCR)-beta gene enhancer during early $\mathrm{T}$ cell development: implications for the control of TCR-beta locus recombination. J. Exp. Med. 192: 625-636

156 Whitehurst C. E., Schlissel M. S. and Chen J. (2000) Deletion of germline promoter PD beta 1 from the TCR beta locus causes hypermethylation that impairs D beta 1 recombination by multiple mechanisms. Immunity 13: 703-714

157 Maraschio P., Zuffardi O., Dalla Fior T. and Tiepolo L. (1988) Immunodeficiency, centromeric heterochromatin instability of chromosomes 1, 9 and 16, and facial anomalies: the ICF syndrome. J. Med. Genet. 25: 173-180

158 Viegas-Pequignot E. and Dutrillaux B. (1976) Segmentation of human chromosomes induced by 5-ACR (5-azacytidine). Hum. Genet. 34: 247-254

159 Jeanpierre M., Turleau C., Aurias A., Prieur M., Ledeist F., Fischer A. et al. (1993) An embryonic-like methylation pattern of classical satellite DNA is observed in ICF syndrome. Hum. Mol. Genet. 2: 731-735

160 Hansen R. S., Wijmenga C., Luo P., Stanek A. M., Canfield T. K., Weemaes C. M. et al. (1999) The DNMT3B DNA methyltransferase gene is mutated in the ICF immunodeficiency syndrome. Proc. Natl. Acad. Sci. USA 96: 14412-14417

161 Hagberg B., Aicardi J., Dias K. and Ramos O. (1983) A progressive syndrome of autism, dementia, ataxia and loss of purposeful hand use in girls: Rett's syndrome: report of 35 cases. Ann. Neurol. 14: 471-479

162 Amir R. E., Van den Veyver I. B., Wan M., Tran C. Q., Francke U. and Zoghbi H. Y. (1999) Rett syndrome is caused by mutations in X-linked MECP2, encoding methyl- CpG-binding protein 2. Nat. Genet. 23: $185-188$

163 Guy J., Hendrich B., Holmes M., Martin J. E. and Bird A. (2001) A mouse Mecp2-null mutation causes neurological symptoms that mimic Rett syndrome. Nat. Genet. 27: 322-326

164 Chen R. Z., Akbarian S., Tudor M. and Jaenisch R. (2001) Deficiency of methyl-CpG binding protein-2 in CNS neurons results in a Rett-like phenotype in mice. Nat. Genet. 27: $327-331$

165 Gibbons R. J., Picketts D. J., Villard L. and Higgs D. R. (1995) Mutations in a putative global transcriptional regulator cause $\mathrm{X}$-linked mental retardation with alpha-thalassemia (ATR-X syndrome). Cell 80: 837-845

166 Gibbons R. J., McDowell T. L., Raman S., O’Rourke D. M., Garrick D., Ayyub H. et al. (2000) Mutations in ATRX, encoding a SWI/SNF-like protein, cause diverse changes in the pattern of DNA methylation. Nat. Genet. 24: 368-371

167 Falls J. G., Pulford D. J., Wylie A. A. and Jirtle R. L. (1999) Genomic imprinting: implications for human disease. Am. J. Pathol. 154: 635-647

168 Cassidy S. B. and Schwartz S. (1998) Prader-Willi and Angelman syndromes. Disorders of genomic imprinting. Medicine (Baltimore) 77: 140-151

169 Knoll J. H., Nicholls R. D., Magenis R. E., Graham J. M. Jr, Lalande M. and Latt S. A. (1989) Angelman and Prader-Willi syndromes share a common chromosome 15 deletion but differ in parental origin of the deletion. Am. J. Med. Genet. 32: $285-290$
170 Li M., Squire J. A. and Weksberg R. (1998) Overgrowth syndromes and genomic imprinting: from mouse to man. Clin. Genet. 53: $165-170$

171 Maher E. R. and Reik W. (2000) Beckwith-Wiedemann syndrome: imprinting in clusters revisited. J. Clin. Invest. 105: 247-252

172 Verkerk A. J., Pieretti M., Sutcliffe J. S., Fu Y. H., Kuhl D. P., Pizzuti A. et al. (1991) Identification of a gene (FMR-1) containing a CGG repeat coincident with a breakpoint cluster region exhibiting length variation in fragile $\mathrm{X}$ syndrome. Cell 65: $905-914$

173 Coffee B., Zhang F., Warren S. T. and Reines D. (1999) Acetylated histones are associated with FMR1 in normal but not fragile X-syndrome cells. Nat. Genet. 22: $98-101$

174 Richardson B. (1986) Effect of an inhibitor of DNA methylation on T cells. II. 5-Azacytidine induces self-reactivity in antigen-specific T4+ cells. Hum. Immunol. 17: 456-470

175 Richardson B. C., Liebling M. R. and Hudson J. L. (1990) CD4+ cells treated with DNA methylation inhibitors induce autologous B cell differentiation. Clin. Immunol. Immunopathol. 55: 368-381

176 Yung R., Powers D., Johnson K., Amento E., Carr D., Laing T. et al. (1996) Mechanisms of drug-induced lupus. II. T cells overexpressing lymphocyte function-associated antigen 1 become autoreactive and cause a lupuslike disease in syngeneic mice. J. Clin. Invest. 97: 2866-2871

177 Cornacchia E., Golbus J., Maybaum J., Strahler J., Hanash S. and Richardson B. (1988) Hydralazine and procainamide inhibit T cell DNA methylation and induce autoreactivity. J. Immunol. 140: 2197-2200

178 Richardson B., Scheinbart L., Strahler J., Gross L., Hanash S. and Johnson M. (1990) Evidence for impaired T cell DNA methylation in systemic lupus erythematosus and rheumatoid arthritis. Arthritis Rheum. 33: 1665-1673

179 Corvetta A., Della Bitta R., Luchetti M. M. and Pomponio G. (1991) 5-Methylcytosine content of DNA in blood, synovial mononuclear cells and synovial tissue from patients affected by autoimmune rheumatic diseases. J. Chromatogr. 566: 481-491

180 Yung R. L., Quddus J., Chrisp C. E., Johnson K. J. and Richardson B. C. (1995) Mechanism of drug-induced lupus. I. Cloned Th2 cells modified with DNA methylation inhibitors in vitro cause autoimmunity in vivo. J. Immunol. 154: 3025-3035

181 Baylin S. B., Herman J. G., Graff J. R., Vertino P. M. and Issa J. P. (1998) Alterations in DNA methylation: a fundamental aspect of neoplasia. Adv. Cancer Res. 72: 141-196

182 Costello J. F. and Plass C. (2001) Methylation matters. J. Med. Genet. 38: 285-303

183 Jones P. A. and Laird P. W. (1999) Cancer epigenetics comes of age. Nat. Genet. 21: 163-167

184 Baylin S. B. and Herman J. G. (2000) DNA hypermethylation in tumorigenesis: epigenetics joins genetics. Trends Genet. 16: $168-174$

185 Sakai T., Toguchida J., Ohtani N., Yandell D. W., Rapaport J. M. and Dryja T. P. (1991) Allele-specific hypermethylation of the retinoblastoma tumor-suppressor gene. Am. J. Hum. Genet. 48: $880-888$

186 Ohtani-Fujita N., Dryja T. P., Rapaport J. M., Fujita T., Matsumura S., Ozasa K. et al. (1997) Hypermethylation in the retinoblastoma gene is associated with unilateral, sporadic retinoblastoma. Cancer Genet. Cytogenet. 98: $43-49$

187 Prowse A. H., Webster A. R., Richards F. M., Richard S., Olschwang S., Resche F. et al. (1997) Somatic inactivation of the VHL gene in Von Hippel-Lindau disease tumors. Am. J. Hum. Genet. 60: 765-771

188 Kissil J. L., Feinstein E., Cohen O., Jones P. A., Tsai Y. C., Knowles M. A. et al. (1997) DAP-kinase loss of expression in various carcinoma and B-cell lymphoma cell lines: possible 
implications for role as tumor suppressor gene. Oncogene 15: 403-407

189 Herman J. G., Umar A., Polyak K., Graff J. R., Ahuja N., Issa J. P. et al. (1998) Incidence and functional consequences of hMLH1 promoter hypermethylation in colorectal carcinoma. Proc. Natl. Acad. Sci. USA 95: 6870-6875.

190 Veigl M. L., Kasturi L., Olechnowicz J., Ma A. H., Lutterbaugh J. D., Periyasamy S. et al. (1998) Biallelic inactivation of hMLH1 by epigenetic gene silencing, a novel mechanism causing human MSI cancers. Proc. Natl. Acad. Sci. USA 95: $8698-8702$

191 Esteller M., Silva J. M., Dominguez G., Bonilla F., MatiasGuiu X., Lerma E. et al. (2000) Promoter hypermethylation and BRCA1 inactivation in sporadic breast and ovarian tumors. J. Natl. Cancer Inst. 92: 564-569

192 Issa J. P., Ottaviano Y. L., Celano P., Hamilton S. R., Davidson N. E. and Baylin S. B. (1994) Methylation of the oestrogen receptor $\mathrm{CpG}$ island links ageing and neoplasia in human colon. Nat. Genet. 7: 536-540

193 Toyota M., Ahuja N., Ohe-Toyota M., Herman J. G., Baylin S. B. and Issa J. P. (1999) CpG island methylator phenotype in colorectal cancer. Proc. Natl. Acad. Sci. USA 96: 8681-8686

194 Baylin S. B., Belinsky S. A. and Herman J. G. (2000) Aberrant methylation of gene promoters in cancer - concepts, misconcepts and promise. J. Natl. Cancer Inst. 92: 1460-1461

195 Holliday R. (1987) The inheritance of epigenetic defects. Science 238: $163-170$

196 Romanov G. A. and Vaniushin B. F. (1980) [Intragenomic specificity of DNA methylation in animals. Qualitative differences in tissues and changes in methylation of repeating sequences during aging, carcinogenesis and hormonal induction]. Mol. Biol. (Mosk.) 14: 357-368

197 Mays-Hoopes L., Chao W., Butcher H. C. and Huang R. C. (1986) Decreased methylation of the major mouse long interspersed repeated DNA during aging and in myeloma cells. Dev. Genet. 7: 65-73

198 Wilson V. L., Smith R. A., Ma S. and Cutler R. G. (1987) Genomic 5-methyldeoxycytidine decreases with age. J. Biol. Chem. 262: 9948-9951

199 Singhal R. P., Mays-Hoopes L. L. and Eichhorn G. L. (1987) DNA methylation in aging of mice. Mech. Ageing Dev. 41: 199-210
200 Vanyushin B. F., Nemirovsky L. E., Klimenko V. V., Vasiliev V. K. and Belozersky A. N. (1973) The 5-methylcytosine in DNA of rats. Tissue and age specificity and the changes induced by hydrocortisone and other agents. Gerontologia 19: $138-152$

201 Romanov G. A. and Vanyushin B. F. (1981) Methylation of reiterated sequences in mammalian DNAs. Effects of the tissue type, age, malignancy and hormonal induction. Biochim. Biophys. Acta 653: 204-218

202 Rath P. C. and Kanungo M. S. (1989) Methylation of repetitive DNA sequences in the brain during aging of the rat. FEBS Lett. 244: 193-198

203 Ono T., Shinya K., Uehara Y. and Okada S. (1989) Endogenous virus genomes become hypomethylated tissue - specifically during aging process of C57BL mice. Mech. Ageing Dev. 50: $27-36$

204 Golbus J., Palella T. D. and Richardson B. C. (1990) Quantitative changes in $\mathrm{T}$ cell DNA methylation occur during differentiation and ageing. Eur. J. Immunol. 20: 1869-1872

205 Ono T., Uehara Y., Kurishita A., Tawa R. and Sakurai H. (1993) Biological significance of DNA methylation in the ageing process. Age Ageing 22: S34-43

206 Ono T., Tawa R., Shinya K., Hirose S. and Okada S. (1986) Methylation of the c-myc gene changes during aging process of mice. Biochem. Biophys. Res. Commun. 139: 1299-1304

207 Ono T., Takahashi N. and Okada S. (1989) Age-associated changes in DNA methylation and mRNA level of the c-myc gene in spleen and liver of mice. Mutat. Res. 219: 39-50

208 Issa J. P. (1999) Aging, DNA methylation and cancer. Crit. Rev. Oncol. Hematol. 32: 31-43

209 Issa J. P. (2000) CpG-island methylation in aging and cancer. Curr. Top. Microbiol. Immunol. 249: 101-118

210 Santini V., Kantarjian H. M. and Issa J. P. (2001) Changes in DNA methylation in neoplasia: pathophysiology and therapeutic implications. Ann. Intern. Med. 134: 573-586

211 Yung R., Ray D., Eisenbraun J. K., Deng C., Attwood J., Eisenbraun M. D. et al. (2001) Unexpected effects of a heterozygous Dnmt1 null mutation on age-dependent DNA hypomethylation and autoimmunity. J. Gerontol. A Biol. Sci. Med. Sci. 56: B268-B276

\section{$(2)$ To access this journal online: \\ (4P) http://www.birkhauser.ch}

